\title{
Expression of turtle riboflavin-binding protein represses mitochondrial electron transport gene expression and promotes flowering in Arabidopsis
}

\author{
Liang $\mathrm{Li}^{\dagger}$, Li Hu${ }^{\dagger}$, Li-Ping Han, Hongtao Ji, Yueyue Zhu, Xiaobing Wang, Jun Ge, Manyu Xu, Dan Shen ${ }^{*}$ \\ and Hansong Dong*
}

\begin{abstract}
Background: Recently we showed that de novo expression of a turtle riboflavin-binding protein (RfBP) in transgenic Arabidopsis increased $\mathrm{H}_{2} \mathrm{O}_{2}$ concentrations inside leaf cells, enhanced the expression of floral regulatory gene $F D$ and floral meristem identity gene AP1 at the shoot apex, and induced early flowering. Here we report that RfBP-induced $\mathrm{H}_{2} \mathrm{O}_{2}$ presumably results from electron leakage at the mitochondrial electron transport chain (METC) and this source of $\mathrm{H}_{2} \mathrm{O}_{2}$ contributes to the early flowering phenotype.

Results: While enhanced expression of FD and $A P 1$ at the shoot apex was correlated with early flowering, the foliar expression of 13 of 19 METC genes was repressed in RfBP-expressing $\left(\mathrm{RABP}^{+}\right)$plants. Inside RfBP ${ }^{+}$leaf cells, cytosolic $\mathrm{H}_{2} \mathrm{O}_{2}$ concentrations were increased possibly through electron leakage because similar responses were also induced by a known inducer of electron leakage from METC. Early flowering no longer occurred when the repression on METC genes was eliminated by RfBP gene silencing, which restored RfBP ${ }^{+}$to wild type in levels of $F D$ and $A P 1$ expression, $\mathrm{H}_{2} \mathrm{O}_{2}$, and flavins. Flowering was delayed by the external riboflavin application, which brought gene expression and flavins back to the steady-state levels but only caused $55 \%$ reduction of $\mathrm{H}_{2} \mathrm{O}_{2}$ concentrations in RfBP ${ }^{+}$plants. RfBP-repressed METC gene expression remedied the cytosolic $\mathrm{H}_{2} \mathrm{O}_{2}$ diminution by genetic disruption of transcription factor NFXLI and compensated for compromises in FD and AP1 expression and flowering time. By contrast, RfBP resembled a peroxisomal catalase mutation, which augments the cytosolic $\mathrm{H}_{2} \mathrm{O}_{2}$, to enhance FD and AP1 expression and induce early flowering.
\end{abstract}

Conclusions: RfBP-repressed METC gene expression potentially causes electron leakage as one of cellular sources for the generation of $\mathrm{H}_{2} \mathrm{O}_{2}$ with the promoting effect on flowering. The repressive effect on METC gene expression is not the only way by which RfBP induces $\mathrm{H}_{2} \mathrm{O}_{2}$ and currently unappreciated factors may also function under RfBP ${ }^{+}$background.

\section{Background}

Riboflavin (vitamin $\mathrm{B}_{2}$ ) is the precursor of flavin mononucleotide (FMN) and flavin adenine dinucleotide (FAD), essential cofactors for many metabolic enzymes involved in multiple cellular processes, such as mitochondrial electron transport chain (METC) and cellular redox regulation in other cellular compartments [1-3]. Flavin-mediated redox is critical for the generation of reactive oxygen species

\footnotetext{
* Correspondence: dshen@njau.edu.cn; hsdong@njau.edu.cn

${ }^{\dagger}$ Equal contributors

Department of Plant Pathology, Nanjing Agricultural University and State Ministry of Education Key Laboratory of Integrated Management of Crop Pathogens and Insect Pests, Nanjing 210095, China
}

(ROS) of different types [4-6], such as superoxide radical $\mathrm{O}_{2}^{--}[7,8]$ and hydrogen peroxide $\mathrm{H}_{2} \mathrm{O}_{2}[4,9] . \mathrm{H}_{2} \mathrm{O}_{2}$ is a more stable ROS form, than $\mathrm{O}_{2}^{--}$for example, and thus frequently functions as a cellular signal to regulate multiple aspects of plant development $[10,11]$.

ROS can be generated by a number of redox processes outside and inside plant cells [9,11-13]. An intracellular source of ROS is redox-associated electron-carrier protein complexes I to IV in METC [14]. If METC functions normally, an electron tetrad (four electrons as a group) in each transport round is transferred through the carrier-protein complexes to a single $\mathrm{O}_{2}$ accepter, which reduces $\mathrm{O}_{2}$ to form $\mathrm{H}_{2} \mathrm{O}$ with protons from 
coenzymes $\mathrm{NADH}_{2}$ (nicotinamide adenine dinucleotide carrying two protons) and $\mathrm{FADH}_{2}$ [15-17]. Under METC dysfunction, single electrons are transferred to $\mathrm{O}_{2}$ to generate $\mathrm{O}_{2}^{--}$, which is further converted to $\mathrm{H}_{2} \mathrm{O}_{2}$ [18-21]. This process is known as electron leakage and increases cytosolic concentrations of $\mathrm{H}_{2} \mathrm{O}_{2}$ through subcellular trafficking [11,13]. Electron leakage and $\mathrm{H}_{2} \mathrm{O}_{2}$ generation may take place in protein complexes I, II, and III in living organisms including plants [22-25]. Electron leakage and $\mathrm{H}_{2} \mathrm{O}_{2}$ generation subsequent to complex I inhibition by rotenone, a ketonic chemical compound that interferes with METC, have been well demonstrated in animals $[20,21]$. Because FMN/FMNH ${ }_{2}$ and $\mathrm{FAD} / \mathrm{FADH}_{2}$ serve as redox centers in complexes I and II, respectively, flavins are likely to play a pivotal role in electron leakage and $\mathrm{H}_{2} \mathrm{O}_{2}$ generation from METC $[13,21,26]$.

In agreement with this notion, recently we demonstrated that cell cytosolic $\mathrm{H}_{2} \mathrm{O}_{2}$ concentrations could be altered by modulating concentrations of free flavins (riboflavin, FMN, and FAD) in leaves of Arabidopsis thaliana [13]. Flavin concentrations were modulated by de novo expression of the turtle (Trionyx sinensis japonicus) gene encoding riboflavin-binding protein (RfBP). This protein contains a nitroxyl-terminal ligand-binding domain, which is implicated in molecular interactions, and a carboxyl-terminal phosphorylation domain, which accommodates the riboflavin molecule [27-30]. In the RfBP-expressing $\left(\mathrm{RfBP}^{+}\right)$Arabidopsis plants, RfBP localizes to chloroplasts and binds with riboflavin, resulting in significant decreases of free flavin concentrations. This change accompanies an elevation in the cytosolic level of $\mathrm{H}_{2} \mathrm{O}_{2}$. All these RfBP-conferred responses can be eliminated by nullifying RfBP production under $\mathrm{RfBP}^{+}$ background, and the RfBP gene silencing $\left(\mathrm{RfBP}^{-}\right)$Arabidopsis lines resemble the wild-type (WT) plant in flavin and $\mathrm{H}_{2} \mathrm{O}_{2}$ concentrations [13]. Thus, the alteration of flavin content is an initial force for $\mathrm{H}_{2} \mathrm{O}_{2}$ generation in the plant cytosol. Nevertheless, how altered flavin content induces $\mathrm{H}_{2} \mathrm{O}_{2}$ generation was unclear.

$\mathrm{H}_{2} \mathrm{O}_{2}$ has been implicated in flowering time control [31-35] by the photoperiod pathway, which comprises a number of regulators [36,37]. An essential regulator, the bZIP transcription factor FLOWERING LOCUS D (FD), functions to activate the floral meristem identity (FMI) gene APETALA1 (AP1), which marks the beginning of floral organ formation at the shoot apex [38,39]. At the shoot apex, $F D$ and $A P 1$ are coordinately expressed to promote the growth of floral organ primordia $[38,39]$. The circadian clock is a central player of the photoperiod pathway [36], and $\mathrm{H}_{2} \mathrm{O}_{2}$ serves as an input signal that affects the transcriptional output of the clock and flowering time [35]. Flowering is promoted when the cytosolic $\mathrm{H}_{2} \mathrm{O}_{2}$ level is increased, for example, by enhanced activities of chloroplastic lipoxygenase and ascorbate peroxidase in Arabidopsis [31,32].

In addition to increasing $\mathrm{H}_{2} \mathrm{O}_{2}$, downregulation of leaf flavin content by RfBP also induces early flowering in relation to enhanced expression of floral promoting genes $[13,40]$. Early flowering was a serendipitous phenomenon [13] and was prudently characterized as a constant phenotype of $\mathrm{RfBP}^{+}$plants [40]. This phenotype was eliminated when leaf flavins were brought back by $\mathrm{RfBP}^{-}$to the steady-state levels. RfBP-induced early flowering was correlated with enhanced foliar expression of floral promoting photoperiod genes, but not related to genes in vernalization, autonomous, and gibberellin pathways [40], which provide flowering regulation mechanisms alternative to the photoperiod [41-43]. RfBP-upregulated photoperiod genes encode red/far red light receptor phytochrome PHYA, blue light receptor cryptochromes CRY1 and CRY2, circadian clock oscillator TIMING OF CAB EXPRESSION1 (TOC1), and putative zinc finger transcription factor CONSTANS (CO) proteins [40]. PHYA, CRY1, and CRY2 serve as the entry of the clock and transmit the light signal to the central oscillator, which deploys a TOC1-partnering transcriptional feedback loop to control day-night rhythm of photoperiod gene expression [44-46] and the production of $\mathrm{CO}$ as an output of the clock and an activator of the florigen gene FT in leaves $[45,47]$. Thus, RfBPinduced early flowering is attributable to the photoperiod pathway. RfBP-induced early flowering also correlates with increased expression of $F D$ and $A P 1$ at the shoot apex [40], suggesting the role of RfBP in concurrently enhancing the expression of flowering-related genes assigned to photoperiod, floral regulation, and FMI categories. By contrast, the expression of $F T$ and photoperiod genes in leaves and the expression of $F D$ and $A P 1$ in the shoot apex were no longer enhanced when the $R f B P$ gene was silenced, RfBP protein production canceled, and flavin concentrations were brought back to the steady-state levels [40], confirming the initial effects of RfBP modulation on the sequential responses. These findings indicate that leaf flavin content downregulation by RfBP induces early flowering coincidently with increased content of cytosolic $\mathrm{H}_{2} \mathrm{O}_{2}$ and enhanced expression of genes that promote flowering through the photoperiod pathway. However, causal relationships of these responses were unknown. Here, we focus on a particular question: how is $\mathrm{H}_{2} \mathrm{O}_{2}$ induced to affect flowering time under $\mathrm{RfBP}^{+}$background?

In the plant cell, $\mathrm{H}_{2} \mathrm{O}_{2}$ can be generated by multiple sources, such as peroxisomal redox [48,49], chloroplastic metabolisms [31,32], transcriptional regulation related to growth and development [50], and METC as well [11,13]. However, which of these sources is related to flowering time control was unknown. In this study, we elucidate that leaf flavin content downregulation by RfBP $[13,40]$ induces $\mathrm{H}_{2} \mathrm{O}_{2}$ generation presumably through electron leakage 
from METC and this source of $\mathrm{H}_{2} \mathrm{O}_{2}$ causes a promoting effect on flowering in Arabidopsis.

\section{Results}

RfBP induces early flowering and expression of $F D$ and AP1 genes

Previously we tested WT, $\mathrm{RfBP}^{+}$, and $\mathrm{RfBP}^{-}$plants under typical short days (8-hour light), atypical short days (12 hours), typical long days (16 hours), or inductive photoperiod (plant shift from short days to long days ) [13,40]. To simplify experimental conditions in this study, we investigated those plants grown in typical long days and under this condition we confirmed de novo expression of the $R f B P$ gene in $\mathrm{RfBP}^{+}$and gene silencing in $\mathrm{RfBP}^{-}$. The gene was highly expressed (Figure 1a) and a substantial quantity of the RfBP protein was produced (Figure 1b) in leaves of $\mathrm{RfBP}^{+}$in contrast to the absence of gene expression and protein production in the WT plant. The gene expression and protein production were markedly reduced in the $\mathrm{RfBP}^{-}$plant (Figure 1a,b). Flowering was promoted in $\mathrm{RfBP}^{+}$compared to WT or $\mathrm{RfBP}^{-}$plants (Figure 1c). WT plants needed 24 days to flower with 20 rosette leaves (Figure 1d). RfBP ${ }^{-}$resembled WT in flowering time and rosette leaf number while $\mathrm{RFBP}^{+}$flowered 6 days earlier with a reduction of 11 rosette leaves than WT (Figure 1d). Then, we studied the floral initiation marker gene $A P 1$
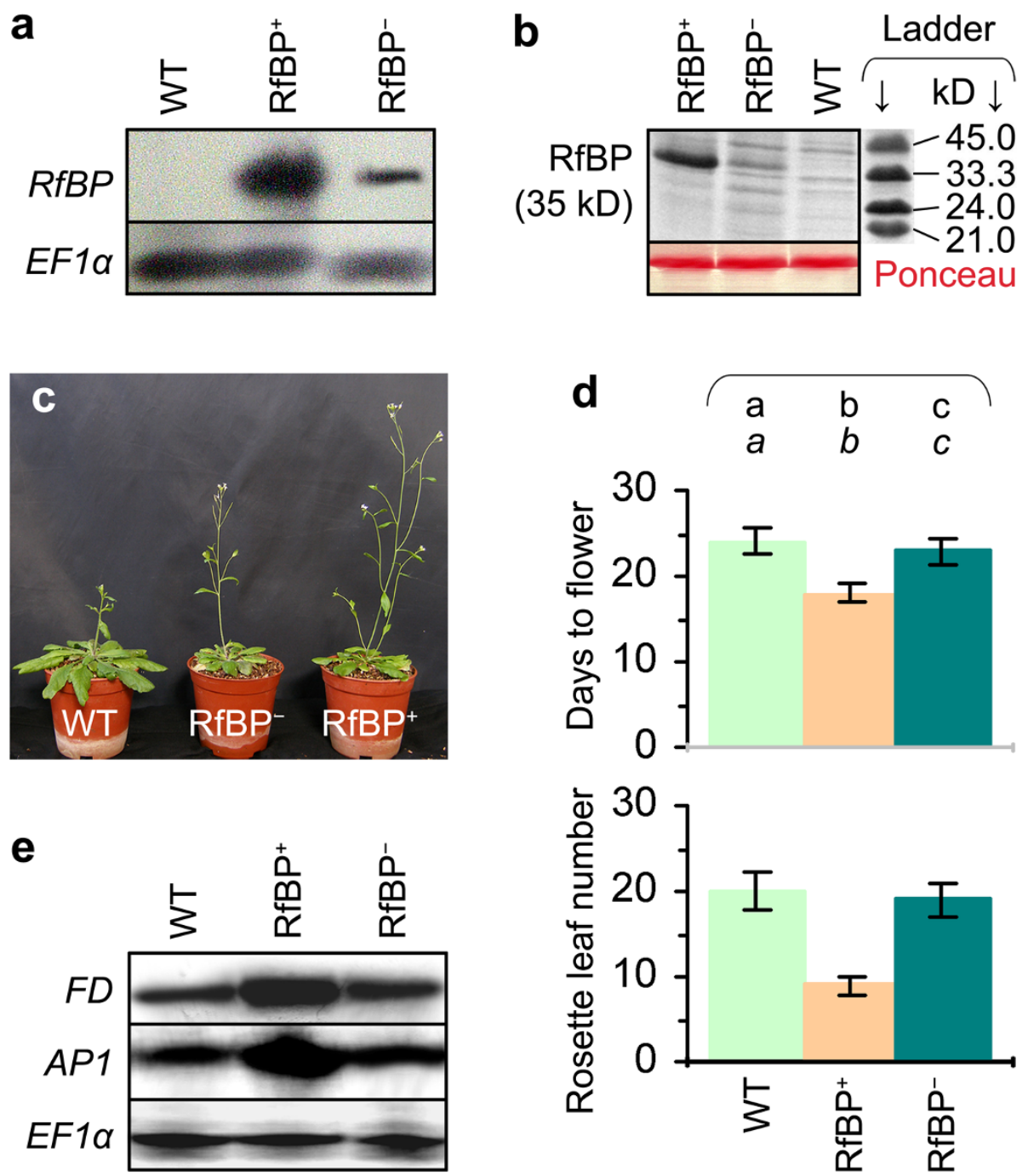

Figure 1 De novo expression of the turtle RfBP gene and its effects on flowering and expression of $F D$ and AP1 genes in Arabidopsis. WT, $\mathrm{RfBP}^{+}$, and RfBP${ }^{-}$plants were grown in long days. Northern blotting (a) and electrophoresis (b) analyses were performed with RNAs and proteins, respectively, isolated from the two youngest expanded leaves of 12-day-old plants. Gel staining with in (b) verified consistent loading of proteins. Three-week-old plants were photographed (c). Days to flower and rosette leaf number were scored as mean values \pm standard deviations from seven experimental repeats each containing 50 plants (d). On bar graphs, different letters shown in regular and italic fonts indicate significant differences by analysis of variance using Fisher's least significant difference test and Tukey-Kramer's test, respectively $(n=7 ; P<0.01)$. FD and AP1 were analyzed by Northern blotting with RNAs from shoot apices of 12-day-old plants (e). In (a) and (e), the constitutively expressed EF1a gene was used as a reference. 
and its regulator gene $F D$ because enhanced expression of both genes well reflects the molecular basis of RfBPinduced early flowering [40]. We found that $F D$ and $A P 1$ displayed higher expression levels in $\mathrm{RfBP}^{+}$than in WT and $\mathrm{RfBP}^{-}$plants on 12 days after stratification, 6 days before $\mathrm{RfBP}^{+}$flowering in typical long days (Figure 1e). Therefore, it is pertinent that we further explore the molecular mechanism that underpins RfBP-induced early flowering under typical long day condition.

\section{Flavin downregulation by RfBP represses expression of METC genes}

Based on the RfBP-regulated transcriptome profiling by the Affymetrix Arabidopsis genome ATH1 array (http:// www.ncbi.nlm.nih.gov/geo/query/acc.cgi?acc=GSE18417), expression levels of 13 of 19 METC genes were reduced 2 to 4 times in $\mathrm{RfBP}^{+}$compared to the WT plant (Figure 2). The rest six genes encode: (1) NADH dehydrogenase (ubiquinone, $\mathrm{CoQ}$ ) Fe-S protein; (2) iron-sulfur protein A; (3) iron-sulfur protein B; (4) iron-sulfur protein C; (5) flavoprotein and (6) alternative oxidase. Proteins encoded by RfBP-repressed METC genes in order are: (1) NADHubiquinone (NADHU) oxidoreductase-related; (2) NADHU oxidoreductase-related; (3) NADHU oxidoreductase B18 subunit; (4) NADHU oxidoreductase 19-kD subunit (NDUFA8) family protein; (5) pridine nucleotidedisulphide oxidoreductase family protein; (6) ubiquinol- cytochrome (Cyt) c reductase (UCCR) complex 7.8-kD protein, putative; (7) putative UCCR complex CoQbiding protein; (8) putative UCCR complex CoQ-biding protein; (9) Cyt c oxidase (UCCO) copper chaperone family protein; (10) UCCO subunit 6b, putative; (11) mitochondrial ATP synthase g subunit family protein; (12) mitochondrial ATP synthase g subunit family protein; and (13) mitochondrial ATP synthase episilon chain. In this list, the last three proteins function in the production of energy and the first 10 ones are all required for electron transport, initiated by NADH in complex I and finished by Cty in complex IV [16] (Figure 2).

The array result was confirmed by quantitative real-time RT-PCR analyses of gene expression in leaves. Based on ratios of transcript quantities to the constitutively expressed $E F 1 \alpha$ gene used as a reference, expression levels of the 13 METC genes were significantly $(P<0.01)$ lower in $\mathrm{RfBP}^{+}$than in WT plants (Figure 3). The difference was more explicitly recognized by presentation of $\mathrm{RfBP}^{+}$to WT ratios of gene transcript amounts (Additional file 1: Figure S1). Quantitative analyses did not detect evident repression of METC gene expression in $\mathrm{RfBP}^{-}$plants. Instead, the 13 METC genes were expressed similarly in $\mathrm{RfBP}^{-}$and WT leaves (Figure 3). This, repression of METC gene expression was caused by de novo expression of $R f B P$.

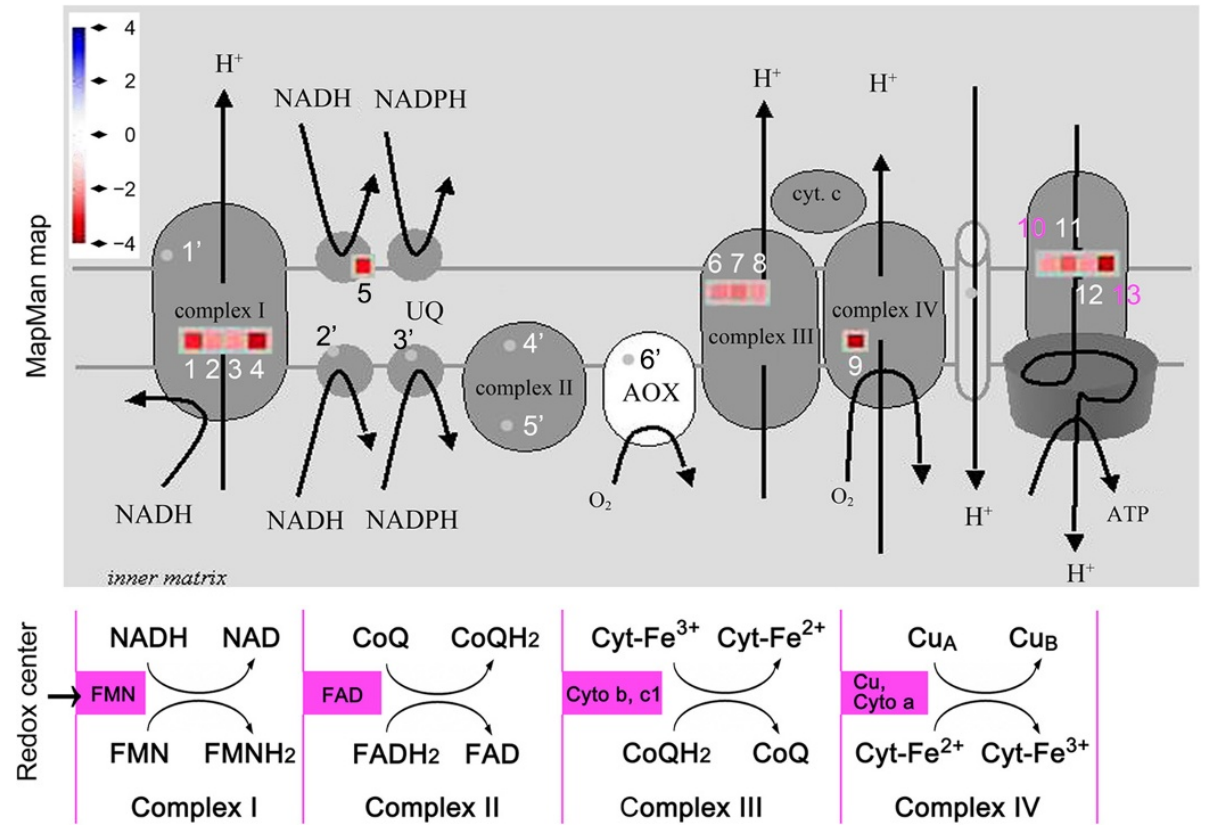

Figure 2 The effect of RfBP on METC gene expression. The MapMan program [85] was employed to analyze previously obtained data (http:// www.ncbi.nlm.nih.gov/geo/query/acc.cgi?acc=GSE18417), show scaled reciprocal values of ratios of gene expression levels between RfBP ${ }^{+}$and WT plants, and locate RfBP-affected genes with colored square patterns and other genes with grey dots in METC. Electron-carrier protein complexes and redox centers are indicated. In the MapMan map, RfBP-repressed genes are digitally coded (1-13) and the other genes are numbered with superscript commas. RfBP-repressed METC gene numbers 1-13 were used constantly in this figure and Figures 4, 5, and 10. See text for products encoded by METC genes. 


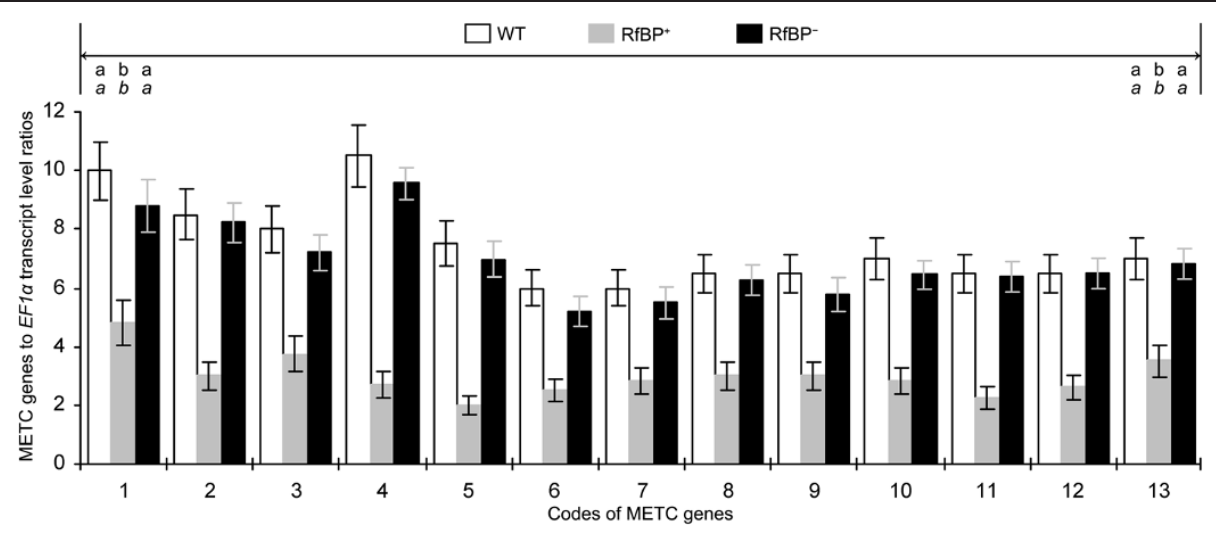

Figure 3 Relative levels of METC gene expression in WT, $\mathrm{RfBP}^{+}$, and $\mathrm{RfBP}^{-}$plants. Water and aqueous solutions of riboflavin and rotenone were used separately to immerse seeds and treat 10-day-old plants by spraying over plant tops. Gene expression in the two youngest expanded leaves of 12-day-old plants was analyzed by real-time RT-PCR using EF1a as a reference gene. Data shown are average values \pm standard deviations of results from six experimental repeats each containing 15 individuals of 12-day-old plants. Different letters in regular and italic fonts indicate significant differences by analysis of variance using Fisher's least significant difference test and Tukey-Kramer's test, respectively $(n=6 ; P<0.01)$, for every of 13 data pairs shown within the range of bidirectional arrowhead line.

We analyzed the relationship between the dual roles of RfBP in reducing METC gene expression and flavin concentrations. The 13 RfBP-repressed genes function in electron-carrier protein complexes I to IV while I and II employ $\mathrm{FMN} / \mathrm{FMNH}_{2}$ and $\mathrm{FAD} / \mathrm{FADH}_{2}$ as redox centers, respectively [14]. Thus, the suppression of METC gene expression might be attributed to flavin content reduction by RfBP. This hypothesis was validated by the pharmacological study in which plants were fed with an aqueous riboflavin solution or treated with water in the experimental control group. The 13 METC genes were expressed to greater extents in all plants following riboflavin feeding treatment compared to control, and in riboflavin-fed $\mathrm{RfBP}^{+}$plants all of gene transcripts were retrieved approximately to the levels in water-treated WT plants (Figure 4). Meanwhile, the intrinsic flavin concentrations were increased in all plants following riboflavin feeding treatment, and flavin levels in riboflavin-fed $\mathrm{RfBP}^{+}$plants were retrieved approximately to the steady-state level in water-treated WT plants (Figure 5a). $\mathrm{RfBP}^{-}$performed similarly to WT in the riboflavin-feeding effect on flavin concentrations (Figure $5 \mathrm{a}$ ). Based on statistical analyses, differences between $\mathrm{RfBP}^{+}$and WT or $\mathrm{RfBP}^{-}$plants in METC gene expression levels and the effects of riboflavin feeding treatment were constant and significant $(P<0.01)$ for every gene (Figures 4 and $5 \mathrm{a}$ ). Therefore, the suppression of METC gene expression is attributable to flavin content downregulation by RfBP.

\section{Repressed METC gene expression accompanies $\mathrm{H}_{2} \mathrm{O}_{2}$} generation presumably through electron leakage As stated above, the repression of METC gene expression might impair METC functions and cause $\mathrm{H}_{2} \mathrm{O}_{2}$ generation through electron leakage. Electrons leak mainly from electron-carrier protein complex I or III and occasionally from complex II $[24,25,51]$. Because the redox center is FMN/FMNH $H_{2}$ in complex I and FAD/FADH $\mathrm{F}_{2}$ in complex II ([14]; Figure 2), flavin content reduction by RfBP is likely to impair functions of both complexes and induce electron leakage. To verify this hypothesis, we tested $\mathrm{H}_{2} \mathrm{O}_{2}$ in leaves of WT, $\mathrm{RfBP}^{+}$, and $\mathrm{RfBP}^{-}$plants following riboflavin feeding treatment since the treatment eliminated the inhibitive effect of RfBP on METC genes (Figure 4) and restores $\mathrm{RfBP}^{+}$to WT in flowering time [40].

Fluorescent $\mathrm{H}_{2} \mathrm{O}_{2}$ probes Amplex red (AR) and Amplex ultra red (AUR) were employed to visualize $\mathrm{H}_{2} \mathrm{O}_{2}$ in Arabidopsis cells. In reaction with $\mathrm{H}_{2} \mathrm{O}_{2}, A R$ and AUR are converted into resorufin and a resorufin analog, respectively, which emit strong crimson fluorescence [9]. AR can penetrate the plasma membrane and thus probes $\mathrm{H}_{2} \mathrm{O}_{2}$ in the cytosol, whereas, AUR can not penetrate the plasma membrane and thus probes $\mathrm{H}_{2} \mathrm{O}_{2}$ present in the apoplastic space [9]. Apoplastic and cytosolic $\mathrm{H}_{2} \mathrm{O}_{2}$ signals reported by AUR and AR, respectively, are shown in Figure 5b. AUR staining signals were weak and similar in all plants irrespectively of treatment with riboflavin or with water as a control, suggesting low steady-state levels of the apoplastic $\mathrm{H}_{2} \mathrm{O}_{2}$ that was unaffected by RfBP or riboflavin. By contrast, AR staining signals were stronger in all plants treated with water compared to riboflavin, suggesting that riboflavin feeding treatment decreased the quantity of cytosolic $\mathrm{H}_{2} \mathrm{O}_{2}$. Especially, $\mathrm{RfBP}^{+}$plants displayed the strongest signal with water treatment but the signal was highly reduced by riboflavin feeding treatment. Thus, RfBP-induced $\mathrm{H}_{2} \mathrm{O}_{2}$ mainly accumulates in the cytosol and can be decreased by feeding plants with riboflavin. 


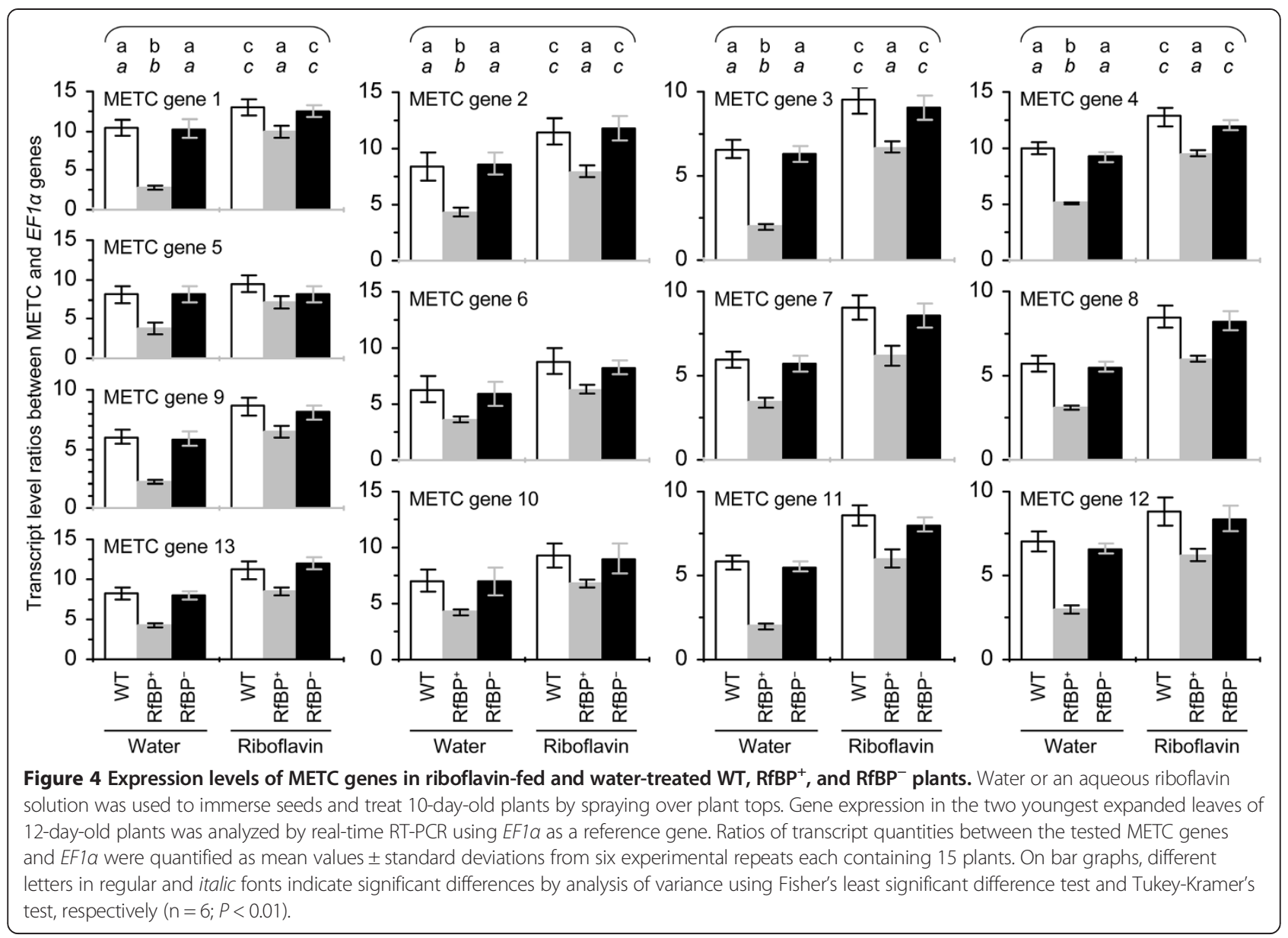

Leaf $\mathrm{H}_{2} \mathrm{O}_{2}$ concentrations were measured. With water treatment, $\mathrm{H}_{2} \mathrm{O}_{2}$ levels were approximately 1.6-fold higher in $\mathrm{RfBP}^{+}$than in WT or $\mathrm{RfBP}^{-}$(Figure 5c). Riboflavin feeding treatment significantly $(P<0.01)$ decreased $\mathrm{H}_{2} \mathrm{O}_{2}$ concentrations in all plants. Unexpectedly, $\mathrm{H}_{2} \mathrm{O}_{2}$ concentrations in riboflavin-fed $\mathrm{RfBP}^{+}$plants were reduced only by $55 \%$, from 831 to $372 \mathrm{ng} / \mathrm{mg}$ fresh leaf weight, still significantly $(P<0.01)$ lower than in watertreated WT $\left(573 \mathrm{ng} / \mathrm{mg}\right.$ ) or $\mathrm{RfBP}^{-}(530 \mathrm{ng} / \mathrm{mg})$ plants (Figure $5 \mathrm{c}$ ). In all cases, however, $\mathrm{H}_{2} \mathrm{O}_{2}$ and flavin levels (Figure 5a,b) were correlated with expression extents of METC genes (Figure 4). These analyses are in agreement with $\mathrm{H}_{2} \mathrm{O}_{2}$ imaging assays and both lines of evidence suggest the possibility that increased cytosolic $\mathrm{H}_{2} \mathrm{O}_{2}$ results from electron leakage in flavin-dependent METC.

This notion was supported indirectly by analyses of METC gene expression and $\mathrm{H}_{2} \mathrm{O}_{2}$ concentrations in plants treated with rotenone, a ketonic chemical that inhibits electron-carrier protein complex I and induces electron leakage from this complex $[18,19]$. Rotenone was dissolved in ethanol and used as a water-diluted solution containing $0.1 \%$ ethanol to treat plants, and plants were treated with $0.1 \%$ ethanol in the experimental control group. Equivalent quantities of the 13 transcripts were detected in rotenone-treated and control plants irrespectively of genotype, WT or $\mathrm{RfBP}^{+}$(Figure 6; Additional file 2: Figure S2). In $\mathrm{RfBP}^{+}$, however, rotenone treatment further reduced gene expression levels on the basis of RfBP-caused repression (Figure 6). This analysis indicated that rotenone and RfBP had a similar effect on the expression of METC genes. In contrast to the inhibitory effect on METC gene expression, rotenone treatment increased $\mathrm{H}_{2} \mathrm{O}_{2}$ concentrations in all plants (Figure 6). $\mathrm{H}_{2} \mathrm{O}_{2}$ concentrations in rotenonetreated WT and $\mathrm{RfBP}^{-}$plants were elevated approximately to $90 \%$ of that in water-treated $\mathrm{RfBP}^{+}$plants, indicating the similar function of rotenone and RfBP. Moreover, rotenone appeared to synergize the role of RfBP in increasing $\mathrm{H}_{2} \mathrm{O}_{2}$ concentrations as $\mathrm{H}_{2} \mathrm{O}_{2}$ in $\mathrm{RfBP}^{+}$was near $50 \%$ increased by rotenone compared to control. The similar effects of rotenone and RfBP on METC gene expression and $\mathrm{H}_{2} \mathrm{O}_{2}$ concentrations (Figures 3, 4, 5 and 6) suggest that RfBP induces $\mathrm{H}_{2} \mathrm{O}_{2}$ generation possibly through electron leakage. 


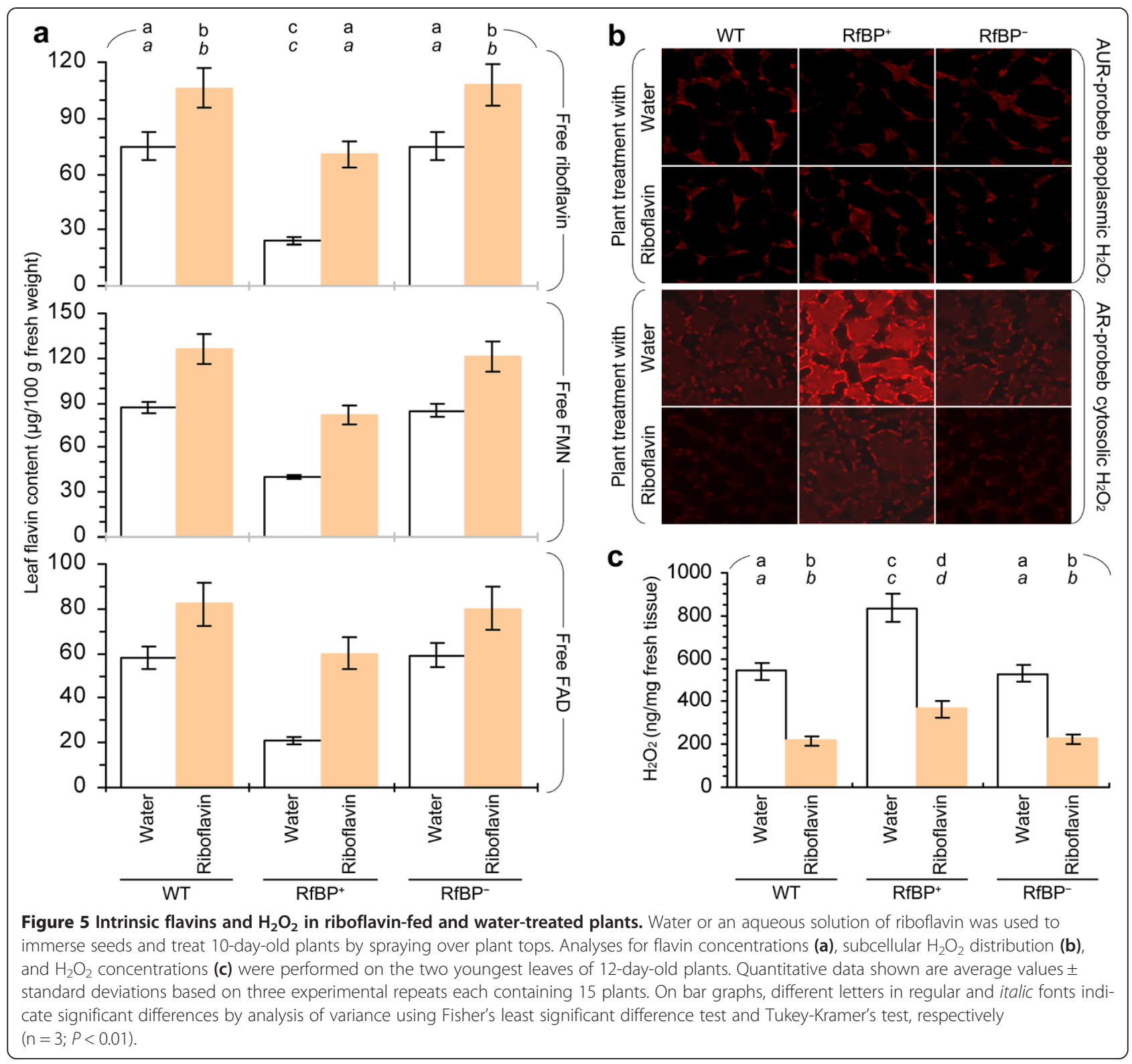

\section{RfBP-induced $\mathrm{H}_{2} \mathrm{O}_{2}$ contributes to early flowering}

All plants flowered later with more rosette leaves when $\mathrm{H}_{2} \mathrm{O}_{2}$ concentrations were decreased by riboflavin feeding treatment compared to treatment with water in control (Figure 7a). The delayed flowering phenotype was coincident with decreased expression of the $F D$ and $A P 1$ genes in shoot apices of plants fed with riboflavin (Figure 7b), which increases expression levels of METC genes in all plants and especially eliminate the inhibitory effect of RfBP on METC gene expression in $\mathrm{RfBP}^{+}$ (Figure 4). In $\mathrm{RfBP}^{+}$, riboflavin feeding treatment retrieved leaf flavins (Figure 5a), the expression of METC genes (Figure 4), FD and $A P 1$ genes (Figure $7 \mathrm{~b}$ ) to approximations of WT levels, and decreased $\mathrm{H}_{2} \mathrm{O}_{2}$ concentrations but did not fully cancel the RfBP-induced quantity (Figure 5c). In this case, $\mathrm{RfBP}^{+}$no longer displayed the early flowering phenotype; instead, they flowered approximately as WT or $\mathrm{RfBP}^{-}$plants (Figure 7a). These analyses indicate that RfBP-induced $\mathrm{H}_{2} \mathrm{O}_{2}$ contributes to the early flowering phenotype in correlation with enhanced expression of $F D$ and $A P 1$ genes in the shoot apex.

\section{The extrinsic application of $\mathrm{H}_{2} \mathrm{O}_{2}$ promotes flowering}

To confirm the promoting effect of $\mathrm{H}_{2} \mathrm{O}_{2}$ on flowering, we performed pharmacological studies in which plants were treated with $\mathrm{H}_{2} \mathrm{O}_{2}$ only or in combination with $\mathrm{H}_{2} \mathrm{O}_{2}$ scavenger catalase. Both compounds were used in aqueous solutions to immerse seeds and treat 10-day-old plants grown on agar medium. We first treated WT 


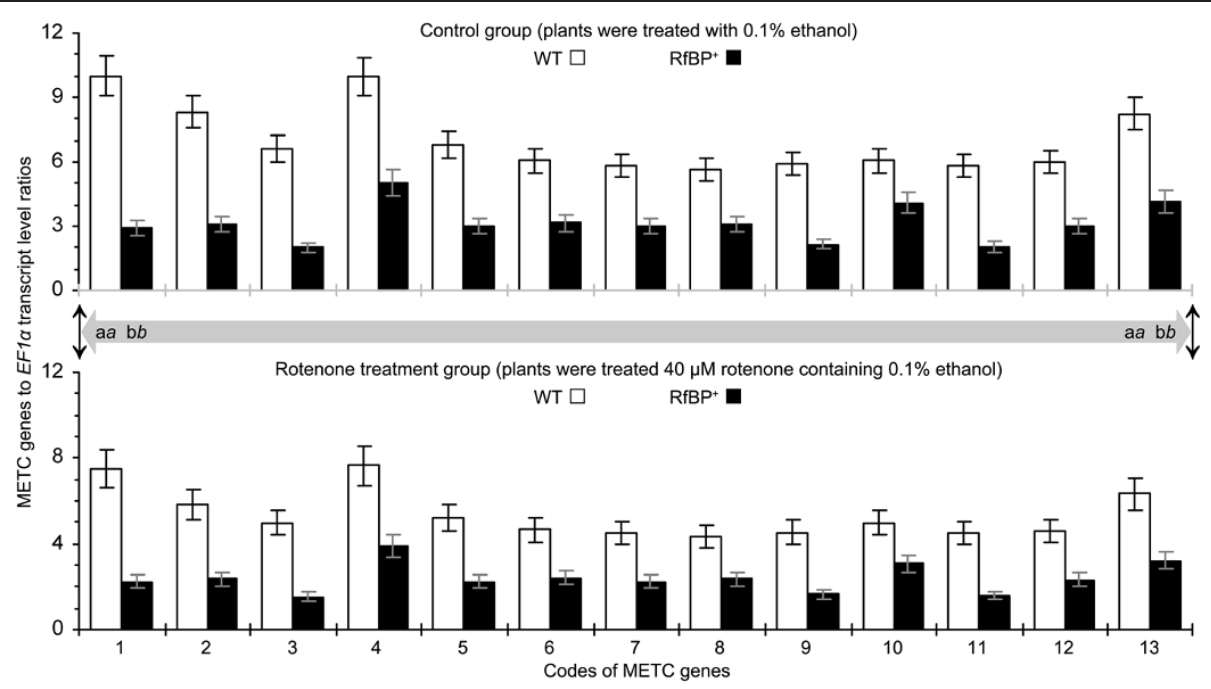

Figure 6 Relative levels of METC gene expression in rotenone-treated and control plants. Ten-day-old plants were treated with an aqueous solution containing $40 \mu \mathrm{M}$ rotenone and $0.1 \%$ ethanol or treated with $0.1 \%$ ethanol in control. Two days later, gene expression in the two youngest expanded leaves was analyzed by real-time RT-PCR using EF1a as a reference gene. Data shown are average values \pm standard deviations of results from six experimental repeats each containing 15 plants. Different letters in regular and italic fonts indicate significant differences by analysis of variance using Fisher's least significant difference test and Tukey-Kramer's test, respectively $(n=6 ; P<0.01)$, for every of 13 data pairs shown in both bar graph panels and within the range indicated by bidirectional arrowhead grey line.
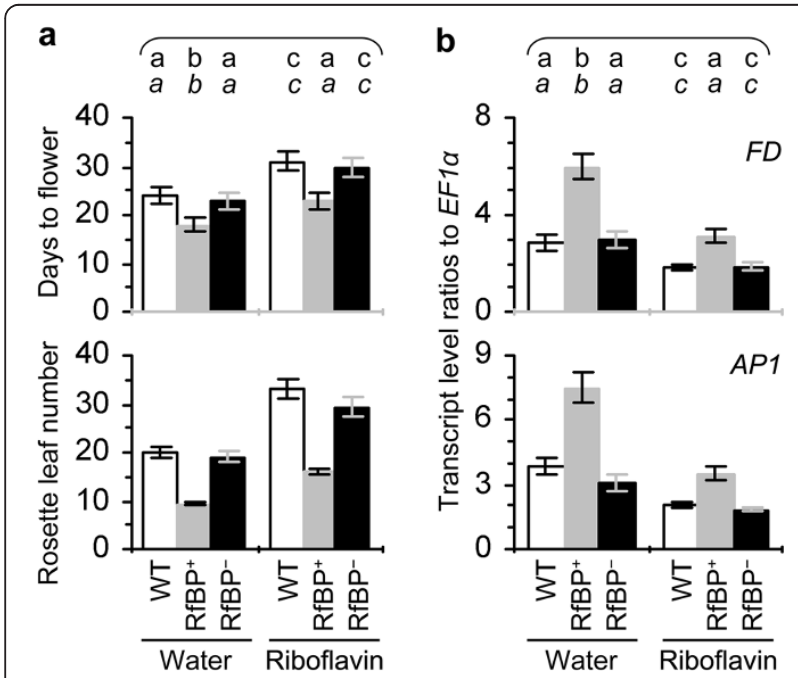

Figure 7 The effects of riboflavin feeding treatment on flowering and expression of $F D$ and $A P 1$. An aqueous solution of riboflavin or water was used to immerse seeds and treat 10-day-old plants by spraying over plant tops. In (a), flowering time and rosette leaf number were scored. In (b), relative levels of FD and AP1 expression in shoot apices of 12-day-old plants were quantified by real-time RT-PCR using the constitutively expressed EF1a gene as a reference. Data shown are average values \pm standard deviations based on three experimental repeats each containing 15 plants. On bar graphs, different letters in regular and italic fonts indicate significant differences by analysis of variance using Fisher's least significant difference test and Tukey-Kramer's test, respectively $(\mathrm{n}=3 ; P<0.01)$. seeds and plants with a range of $\mathrm{H}_{2} \mathrm{O}_{2}$ concentrations and two days later we found that $4 \mathrm{mM} \mathrm{H}_{2} \mathrm{O}_{2}$ well enhanced the expression of $F D$ and $A P 1$ in shoot apices (Figure 8a) and increased the intrinsic level of $\mathrm{H}_{2} \mathrm{O}_{2}$ in leaves (Figure 8b). We further found that $4 \mathrm{mM} \mathrm{H} \mathrm{H}_{2} \mathrm{O}_{2}$ was effective to induce early flowering and reduce rosette leaf number (Figure 8c,d). However, $\mathrm{H}_{2} \mathrm{O}_{2}$ treatment did not cause evident changes in expression levels of METC genes (Additional file 3: Figure S4). Then, we treated seeds and plants with water in control and with $4 \mathrm{mM} \mathrm{H}_{2} \mathrm{O}_{2}$ or a mixture of $4 \mathrm{mM} \mathrm{H}_{2} \mathrm{O}_{2}$ plus $5 \mathrm{U} / \mathrm{ml}$ catalase. We found significant $(P<0.01)$ increases in the intrinsic $\mathrm{H}_{2} \mathrm{O}_{2}$ content (Figure 9a) and enhancements of $F D$ and $A P 1$ expression (Figure 9b), and we also observed the early flowering phenotype (Figure 9c,d), in all plants treated with $\mathrm{H}_{2} \mathrm{O}_{2}$ compared to water. However, these effects were removed by the presence of catalase in the $\mathrm{H}_{2} \mathrm{O}_{2}$ treatment (Figure 9a-d). Thus, the extrinsically applied $\mathrm{H}_{2} \mathrm{O}_{2}$ caused a promoting effect on flowering. More precocious flowering and greater increases in the intrinsic $\mathrm{H}_{2} \mathrm{O}_{2}$ and in $F D$ and $A P 1$ expression levels were observed in $\mathrm{RfBP}^{+}$compared to WT and $\mathrm{RfBP}^{-}$plants under the same treatment conditions (Figure 9a-d). Presumably, the extrinsic (artificially applied) and intrinsic (RfBP-induced) $\mathrm{H}_{2} \mathrm{O}_{2}$ cooperates to promote flowering and enhance $F D$ and $A P 1$ expression at the shoot apex.

\section{$\mathrm{H}_{2} \mathrm{O}_{2}$ from different sources contributes to the similar effect on flowering}

To elucidate whether $\mathrm{H}_{2} \mathrm{O}_{2}$ from different cellular sources contributes to the similar effect on flowering, we determined 


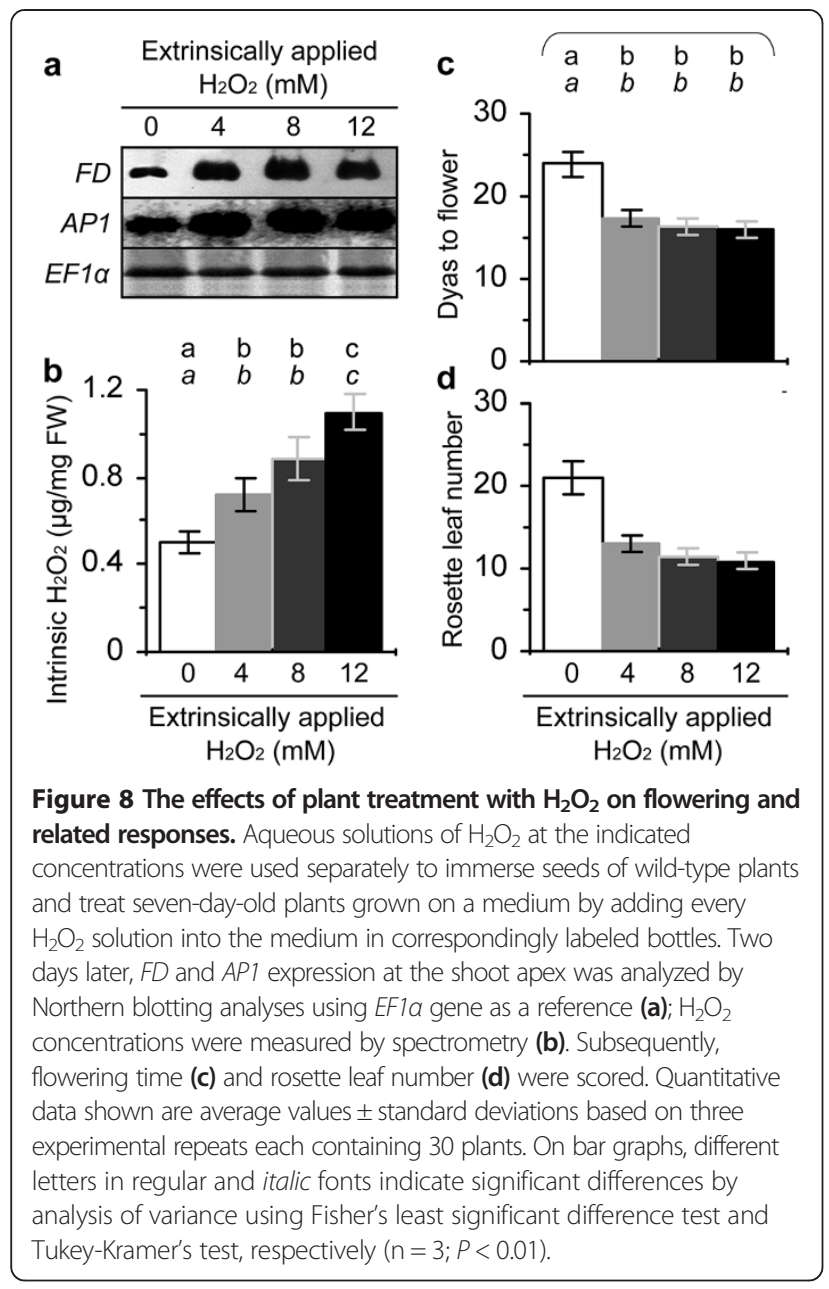

$\mathrm{H}_{2} \mathrm{O}_{2}$ concentrations, $F D$ and $A P 1$ gene expression, and flowering time of Arabidopsis cat 2 and $n f x l 1$ mutants in comparison with WT and $\mathrm{RfBP}^{+}$plants. Due to a mutation in peroxisomal enzyme catalase 2 (Cat2), the cat2 mutant loses $80 \%$ of catalase activity and produces a higher level of the cytosolic $\mathrm{H}_{2} \mathrm{O}_{2}$ compared to the WT plant $[48,49]$. This was confirmed in this study by measuring leaf $\mathrm{H}_{2} \mathrm{O}_{2}$ concentrations, being $43 \%$ higher in cat $2(536 \mathrm{ng} / \mathrm{mg}$ fresh leaves) than in WT (942 ng/mg) [Additional file 4: Figure S5a]. Compared to WT, cat2 displayed higher levels of $F D$ and AP1 expression and was 10 days earlier to flower (Additional file 4: Figure S5b,c). As an indirect result of disruption in the transcription factor NFXL1, the $n f x l 1$ mutant incurs a $20 \%$ decrease of the cytosolic $\mathrm{H}_{2} \mathrm{O}_{2}$ in relative to the steady-state level [50]. Compared to WT, nfxl1 had lower levels of cytosolic $\mathrm{H}_{2} \mathrm{O}_{2}$ and $F D$ and $A P 1$ expression and displayed the late flowering phenotype leaves (Additional file 4: Figure S5b,c). These analyses suggest that $\mathrm{H}_{2} \mathrm{O}_{2}$ from the different sources, Cat2 or NFXL1 defection and RfBP as well, functions similarly to affect flowering time and the expression of $F D$ and $A P 1$.

\section{RfBP compensates for flowering repression in the $n f x / 1$} mutant

Because $R f B P^{+}$and $n f x l 1$ are opposite and likely to counteract the role in $\mathrm{H}_{2} \mathrm{O}_{2}$ content alterations and the effect on flowering, both plants were crossed and the RfBP ${ }^{+}$ $n f x l 1$ hybrid was generated for further analyses. METC genes were expressed similarly in $\mathrm{RfBP}^{+} n f x l 1$ and $\mathrm{RfBP}^{+}$ plants (Figure 10a), suggesting that the $n f x l 1$ mutation was unrelated to METC gene expression. However, the hybrid appeared to be intermediate of both parents in the cytosolic $\mathrm{H}_{2} \mathrm{O}_{2}$ content (Figure 10b), levels of $F D$ and $A P 1$ expression (Figure 10c), flowering time (Figure 10d), and rosette leaf number (Figure 10e). Clearly, $\mathrm{RfBP}^{+}$compensates for flowering repression in the nfxl1 mutant.

\section{Discussion}

This study was attempted to mainly elucidate how $\mathrm{H}_{2} \mathrm{O}_{2}$ is induced by RfBP to affect flowering time on the basis of our recent evidence that early flowering is a constant phenotype conferred by de novo expression of the turtle $R f B P$ gene and associated with a constant increase of leaf $\mathrm{H}_{2} \mathrm{O}_{2}$ concentrations and timely enhanced expression of $F D$ and $A P 1$ at the shoot apex in $\mathrm{RfBP}^{+}$Arabidopsis plants under short days, long days, or inductive photoperiod [40]. Under these conditions, enhanced expression of $F D$ and $A P 1$ is essential for floral organ formation at the shoot apex $[38,39,52]$ and well reflects the molecular basis of RfBP-induced early flowering [40]. In this study, we simplified the experiment system by growing plants only in long days and under this condition we correlated the early flowering phenotype with enhanced expression of $F D$ and $A P 1$, floral regulatory and FMI genes, respectively (Figure 1). Data obtained from multiple experimental repetitions demonstrated that: (i) RfBP represses the expression of 13 of 19 METC genes (Figures 2, 3 and 4; Additional file 1: Figures S1 and Additional file 2: Figure S2) and induces $\mathrm{H}_{2} \mathrm{O}_{2}$ probably results from electron leakage at METC (Figures 5 and 6; Additional file 3: Figure $\mathrm{S} 4$ and Additional file 5: Figure S3); (ii) $\mathrm{H}_{2} \mathrm{O}_{2}$ promotes flowering and enhances the expression of FD and AP1 (Figures 7, 8 and 9); and (iii) the potential electron leakage appears to be one of biochemical sources for the generation of $\mathrm{H}_{2} \mathrm{O}_{2}$ with the promoting effect on flowering (Figure 10; Additional file 4: Figure S5). Previously we showed that the foreign RfBP protein is capable of modulating the intrinsic content of free flavins with physiological and pathological consequences. Inside the $\mathrm{RfBP}^{+}$cell, RfBP binds with riboflavin, reduces quantities of free flavins in leaves, and concomitantly elevates concentrations of the cytosolic $\mathrm{H}_{2} \mathrm{O}_{2}$, which acts in turn to regulate defense responses to a bacterial pathogen [13]. Therefore, flavin content downregulation by the foreign RfBP protein has developmental and defensive consequences. 


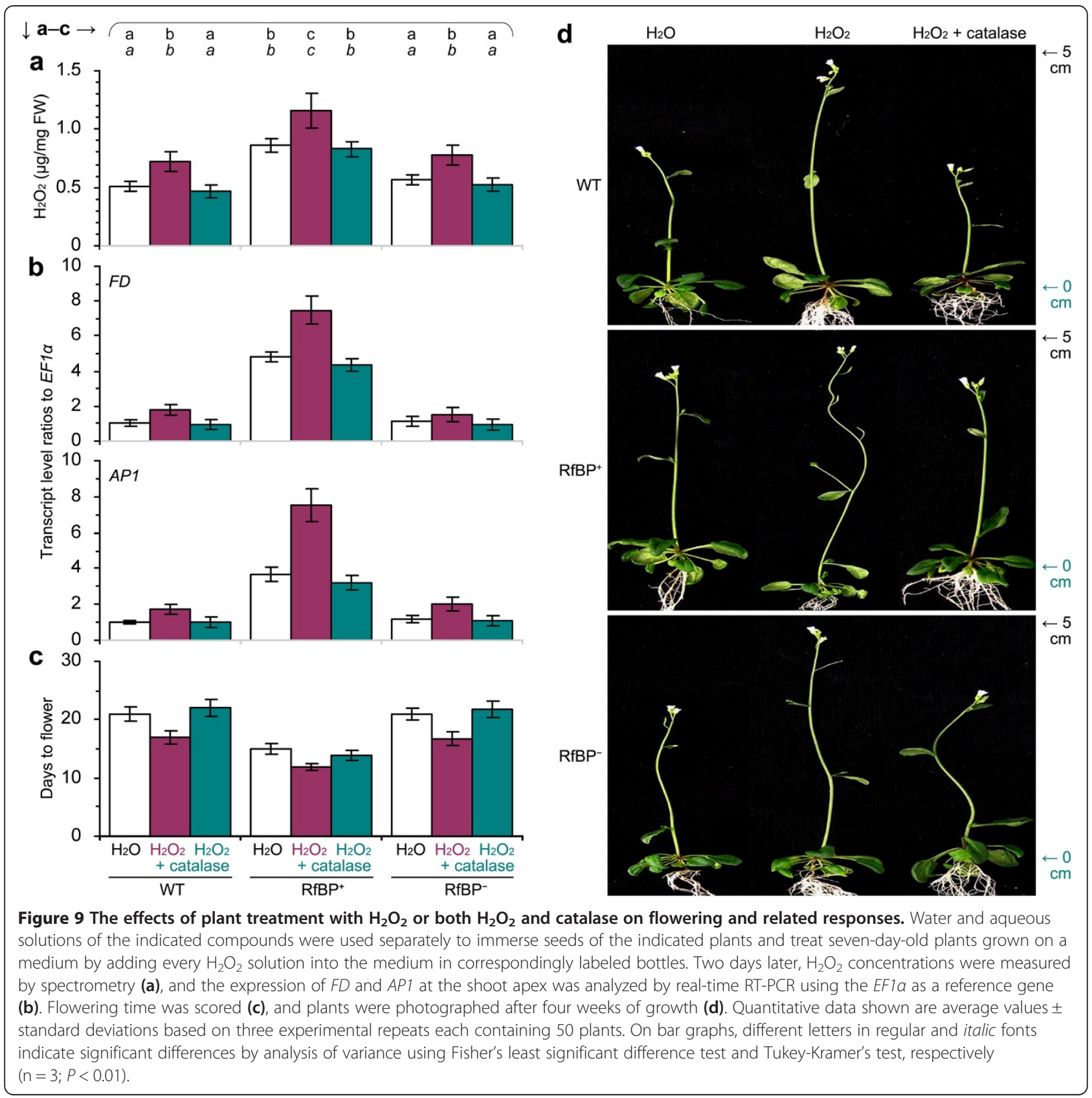

In recent 10 years, genetic modification of the riboflavin biosynthesis pathway alters some aspects of plant development, such as leaf senescence regulated by the COS1 protein characteristic of lumazine synthase, which catalyzes the penultimate step of the riboflavin biosynthesis pathway [53] and is an essential component of jasmonic acid signaling pathway [54]. In plants, moreover, externally applied riboflavin induces plant growth enhancement by activating ethylene signaling pathway [55]. Externally applied riboflavin also induces resistance to pathogens in a manner of salicylic acid dependence or independence according to the type of pathogens $[26,41]$. These findings suggest that changes in riboflavin content cause physiological and pathological responses by affecting phytohormone signaling pathways. Based on our studies detailed here and reported earlier [40], novel functions of flavins have been extended from hormone signaling to flowering time control.

Early flowering associates with spontaneously repressed expression of 13 of 19 METC genes (Figures 2, 3 and 4; Additional file 1: Figure S1 and Additional file 2: Figure S2) and concomitantly elevated cytosolic $\mathrm{H}_{2} \mathrm{O}_{2}$ concentrations 


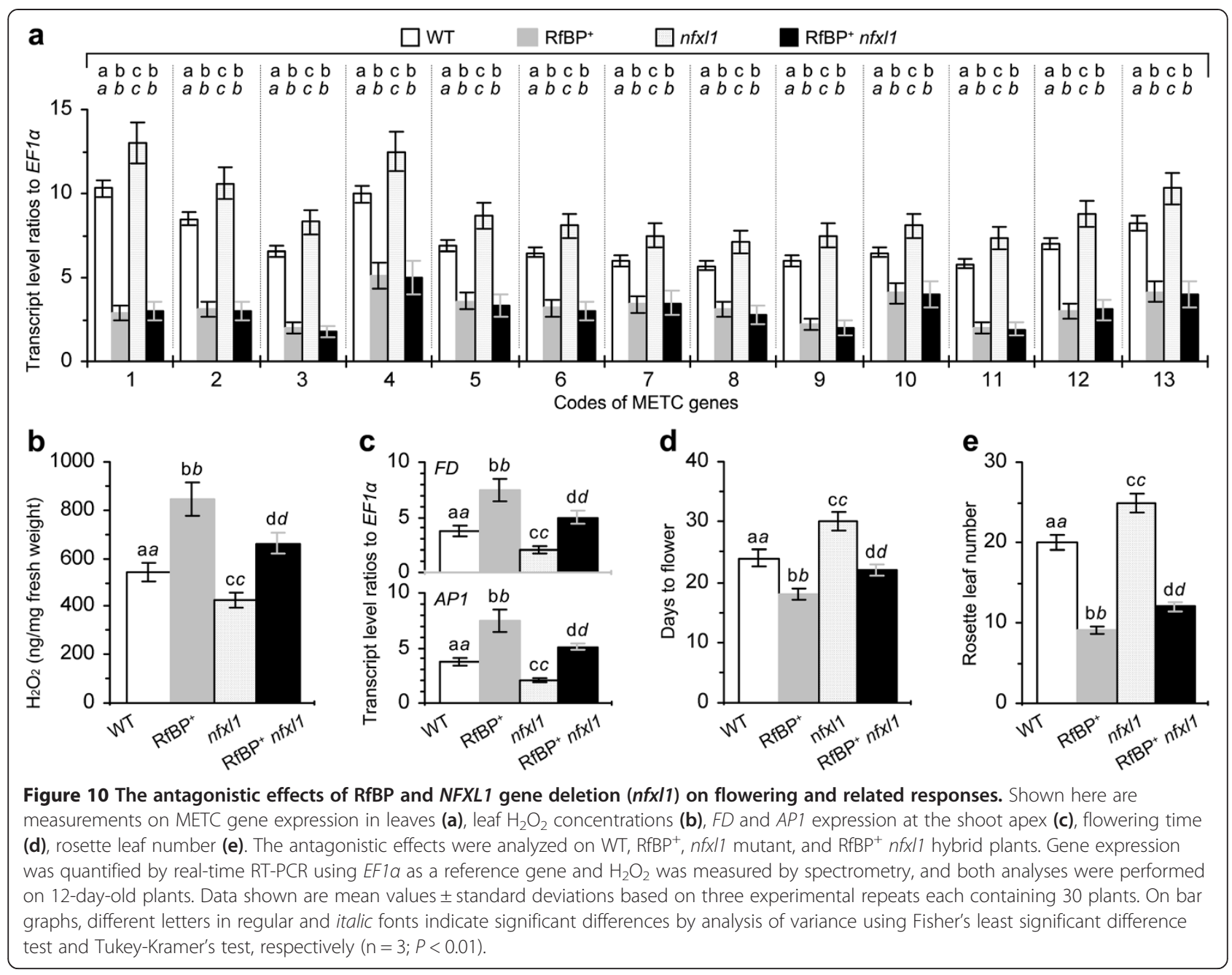

(Figure 5) in $\mathrm{RfBP}^{+}$plants. The repression on METC genes is attributable to decreased concentrations of free flavins in leaves and can be removed either by $\mathrm{RfBP}^{-}$or by riboflavin feeding treatment under $\mathrm{RfBP}^{+}$background (Figures 3 and 4; Additional file 1: Figure S1 and Additional file 2: Figure S2). Based on the roles of $\mathrm{RfBP}^{-}$and riboflavin feeding in restoring $\mathrm{RfBP}^{+}$to WT in flavin content and flowering time, as well as different extents by which riboflavin feeding and RfBP increase $\mathrm{H}_{2} \mathrm{O}_{2}$ concentrations (Figures 5 and 7), increased $\mathrm{H}_{2} \mathrm{O}_{2}$ is at least partially caused by RfBPreduced flavin content and contributes to the early flowering phenotype. On one hand, direct evidence for the promoting effect of $\mathrm{H}_{2} \mathrm{O}_{2}$ on flowering was found in the pharmacological analysis with $\mathrm{H}_{2} \mathrm{O}_{2}$ and catalase (Figures 8 and 9). On the other hand, the coincident decreases in levels of three flavins (Figure 5) conform to dynamics of flavin form conversions. Riboflavin and FMN conversion is reversible [56], while FMN to FAD conversion is irreversible [57]. Accumulation of a particular flavin is concentrationdependent, so that a smaller amount of free riboflavin or FMN results in a smaller amount of FMN or FAD [1].
Therefore, downregulation of free riboflavin is an initial cause of coordinate decreases of free FMN and FAD concentrations and is also a cause of the subsequent effect on flowering time under $\mathrm{RfBP}^{+}$background. In $\mathrm{RfBP}^{+}$, however, although riboflavin feeding treatment only increases $\mathrm{H}_{2} \mathrm{O}_{2}$ but does not retrieve it to the WT level (Figure 5), the treatment enables $\mathrm{RfBP}^{+}$to resemble WT in flavin content, the expression of METC, $F A D$, and $A P 1$ genes, and flowering time in particular (Figures 4 and 7). This discrepancy indicates that downregulating flavin content is not the only mechanism by which RfBP induces $\mathrm{H}_{2} \mathrm{O}_{2}$ and early flowering. Alternatively, the extrinsically applied riboflavin is insufficiently effective as the intrinsically produced flavins to affect cellular redox. At this point, we are unable to pertinently prospect the relationship between flavin-mediated redox and flowering time control based on the riboflavinfeeding experiment.

Regarding to the riboflavin-feeding effect, a question is how the extrinsically applied riboflavin increases the intrinsic flavin concentrations. In plants, riboflavin synthesis, its conversion to FMN, and FMN conversion to FAD are 
predicted to occur in plastids [56,57]. With the cell growth, plastids differentiate into chloroplasts [58], in which RfBP is localized [13]. Flavins are transported by subcellular trafficking and function in processes such as METC [59]. In animals, RfBP functions to mediate the cellular translocation of riboflavin [60,61]. Animals absorb riboflavin directly from dietary sources [62] or produce this vitamin through conversions from ingested FMN and FAD [63]. In both cases, RfBP acts to redistribute riboflavin between cellular compartments, between cells, and from one organ to another $[30,60]$. A similar trafficking mechanism may be responsible for transport of the extrinsic riboflavin into plant cells but this hypothesis remains to be examined.

Regarding to the effects of RfBP on flavin levels and METC gene expression, an important question is how RfBP-decreased flavin concentrations cause $\mathrm{H}_{2} \mathrm{O}_{2}$ generation potentially through electron leakage. Because electron-carrier protein complexes I and II involve the first five of RfBP-repressed 13 genes, and employ FMN/FMNH and $\mathrm{FAD} / \mathrm{FADH}_{2}$ as redox centers (Figure 2), respectively, electrons may leak from both complexes due to RfBPreduced flavin concentrations, resulting in increased concentrations of the cytosolic $\mathrm{H}_{2} \mathrm{O}_{2}$ (Figure 5). This postulation was indirectly supported by circumstantial evidence as following: (i) similar dual roles that rotenone and shortage of flavins play in repressing METC gene expression and increasing $\mathrm{H}_{2} \mathrm{O}_{2}$ (Figures 4, 5 and 6; Additional file 5: Figure S3); (ii) the ternary effects of riboflavin feeding in increasing the intrinsic flavin and METC gene expression levels but decreasing $\mathrm{H}_{2} \mathrm{O}_{2}$ concentrations (Figures 4, 5 and 7); and (iii) the lack of effect of the externally applied $\mathrm{H}_{2} \mathrm{O}_{2}$ on METC gene expression (Figure 6; Additional file 3: Figure S4). In addition, a key point in (i) and (ii) is that the increase of $\mathrm{H}_{2} \mathrm{O}_{2}$ concentrations is a result, but not a cause, of repressed METC gene expression. These analyses suggest the possibility that flavin shortage due to downregulation by RfBP causes the repressive effect as does the toxicity of rotenone [21] on METC to induce electron leakage.

Mechanisms by which rotenone and RfBP repress METC gene expression may be different according to natures of rotenone RfBP, as well as components and functions of METC. Rotenone is a broad-spectrum insecticide, pesticide, and piscicide, is toxic to METC, impairs the role of electron carrier-protein complex I [64] in transport of electron tetrad to single $\mathrm{O}_{2}$ accepter, and inhibits $\mathrm{O}_{2}$ reduction to form $\mathrm{H}_{2} \mathrm{O}$ with protons from $\mathrm{NADH}_{2}$ and $\mathrm{FADH}_{2}$ [15-17]. As regards the effect of RfBP, RfBP-caused shortage of FMN and FAD [13] may lead to insufficient functions of FMN to receive protons from NADPH in complex I and FAD to supply protons for $\mathrm{CoQ}$ in complex II (Figure 2). Electron leakage and $\mathrm{H}_{2} \mathrm{O}_{2}$ generation subsequent to complex I inhibition by rotenone have been well studied in animals $[20,21,64]$, but little was known about whether plants incur a similar inhibition. Owing to the alternative oxidization bypass located between complex III and the inner membrane-associated $\mathrm{CoQ}$, inhibition by rotenone may not cause electron leakage from complex III, but electrons are still likely to leak from complex I or II $[15,16,63]$. Moreover, inhibition of plant complex I expands impacts far beyond the complex itself since a number of metabolic pathways associated with mitochondria and other organelles are altered concomitantly [65]. This also explains a possible way, alternative to reducing flavin content, by which RfBP affects $\mathrm{H}_{2} \mathrm{O}_{2}$ accumulation and flowering time. Repressing METC gene expression seems to be a mode of the rotenone action on METC so that the consequence is similar in rotenonetreated WT and water-treated $\mathrm{RfBP}^{+}$plants (Figure 6; Additional file 2: Figure S2). At present, however, there is no evidence to elucidate the mechanism by which rotenone causes repression of METC gene expression.

In addition to electron leakage from METC, $\mathrm{H}_{2} \mathrm{O}_{2}$ can be generated by many other mechanisms at different sites in plant cells through flavin-mediated cytosolic and peroxisomal redox processes [66]. Cytosolic and peroxisomal redox genes whose expression levels are more than 50\% reduced by RfBP encode single alutaredoxin (At1G03850), thioredoxin (At1G07960), and peroxiredoxin type 2 (At1G60740) proteins and three glutaredoxin (At1G77370, At5G18600, and At5G40370) proteins (http://www.ncbi. nlm.nih.gov/geo/query/acc.cgi?acc=GSE18417). All these proteins are $\mathrm{H}_{2} \mathrm{O}_{2}$ scavengers and may function concomitantly with the potential electron leakage mechanism to elevate cytosolic concentrations of $\mathrm{H}_{2} \mathrm{O}_{2}$ and affect flowering time. As stated above, therefore, the repressive effect on METC gene expression is not the only mechanism by which RfBP induces $\mathrm{H}_{2} \mathrm{O}_{2}$ and promotes flowering under $\mathrm{RfBP}^{+}$ background. Testing of this hypothesis obviously needs numerous challenged genetic, biochemical, and molecular studies. In the present study, we are only able to provide indirect evidence that $\mathrm{RfBP}^{+}$and $n f x l 1$ plants mutually counteract in altering cytosolic $\mathrm{H}_{2} \mathrm{O}_{2}$ concentrations and in the subsequent effects on flowering time and expression of $F D$ and $A P 1$ at the shoot apex (Figure 10; Additional file 4: Figure S5).

With respect to $\mathrm{H}_{2} \mathrm{O}_{2}$ generation and function at different sites in plant cells, a critical question is related to cellular translocation of $\mathrm{H}_{2} \mathrm{O}_{2}$, or how mitochondrial $\mathrm{H}_{2} \mathrm{O}_{2}$ is recruited into flowering time control? Compared to the apoplastic-cytoplasmic translocation [13], intracellular translocation of $\mathrm{H}_{2} \mathrm{O}_{2}$ subsequent to generation in different cellular compartments may play more important roles in regulating multiple physiological processes [11]. The supposed $\mathrm{H}_{2} \mathrm{O}_{2}$ translocation may not depend on free diffusion, but instead, it may comply with certain modes of the selectivity $[67,68]$. In a great attention, the aquaporin channel originally assigned to water transport [69-71] has been implicated in cellular translocation of other small 
compounds [72,73] including $\mathrm{H}_{2} \mathrm{O}_{2}$ [67,74]. Particular aquaporins may mediate $\mathrm{H}_{2} \mathrm{O}_{2}$ translocation for its recruitment into flowering time control. This hypothesis needs to be tested.

\section{Conclusions}

We have shown that RfBP-induced $\mathrm{H}_{2} \mathrm{O}_{2}$ presumably results from METC electron leakage due to flavin downregulation by $\mathrm{RfBP}, \mathrm{H}_{2} \mathrm{O}_{2}$ is a positive regulator of flowering, and the hypothetical electron leakage appears to be one of biochemical sources of $\mathrm{H}_{2} \mathrm{O}_{2}$ with the promoting effect on flowering. In fact, early flowering is a serendipitous phenomenon associated with the de novo expression of $R f B P$, but we don't exactly know what it means with respect to flavin-mediated redox and flowering time control.

\section{Methods}

\section{Plant material and growth conditions}

The RfBP-expressing Arabidopsis thaliana line was previously designated as REAT11 [13] and recently renamed $\mathrm{RfBP}^{+}$[40]. The RfBP-silenced line RfBPi11 generated under $\mathrm{RfBP}^{+}$(REAT11) background [13] was renamed $\mathrm{RfBP}^{-}$[40]. The cat 2 and $n f x l 1$ mutants were generated previously by T-DNA insertion into the Cat 2 gene $[48,49]$ and the NFXl1 gene [50]. Their seeds were purchased from The Arabidopsis Information Resource (http://www. arabidopsis.org) under stock numbers SALK_076998 and SALK_001399, respectively. Seeds of other plants were maintained in this lab. Plants were grown in pots containing potting soil [75] or on Murashigie and Skoog (MS) medium under environment-controlled conditions: $22 \pm$ $1^{\circ} \mathrm{C}, 55 \% \pm 2 \%$ humidity, long days (16-hour light and 8hour dark), and light at $200 \mu \mathrm{M}$ quanta $/ \mathrm{m}^{2} / \mathrm{s}$. Day 0 was considered after stratification. The flowering phenotype was characterized by rosette leaf number and days to flower scored with 50 plants of every genotype in each of seven independent experimental repeats.

\section{Gene expression analysis}

Total RNA was isolated from combined samples of the two youngest expanded leaves excised directly or from shoot apices, which were excised under a binocular microscope, from 15 plants in every of three or six experimental repeats. Isolated RNA was subjected to Northern (RNA) blotting or quantitative real-time reverse transcriptase-polymerase chain reaction (RT-PCR) analyses using the constitutively expressed EF1 $\alpha$ gene as a reference. Northern blots were hybridized to the $R f B P$-specific probe labeled with digoxigenin (EMD Biosci. Inc., Madison, WI, USA). Real-time RT-PCR was performed with specific primers (Additional file 6: Table S1) and followed previously described methods [76,77]. Genes were amplified $<26$ cycles with a range of template concentration increases by $0.5 \mathrm{ng}$ and from 0 to
$3.0 \mathrm{ng}$ in $25 \mu \mathrm{l}$ reaction solutions to select desired doses. The $25 \mu \mathrm{l}$ reaction mixture was composed of $1 \mu \mathrm{l}$ firststrand cDNA diluted 1:10, $2.5 \mu \mathrm{M}$ primer and $1 \times$ SYBR Premix Ex Taq (TaKaRa Biotech. Co., Ltd, Dalian, China). In each of three experimental repeats, all reactions were performed in triplicate with null-template controls in which cDNA was absent. Relative expression level of a tested gene was quantified as the ratio of transcript amounts between the tested gene and EF1 $\alpha$. Relative expression levels were shown directly or converted to percentages for pharmacological treatments vs. control (treatment with water) or for $\mathrm{RfBP}^{+}$and $\mathrm{RfBP}^{-}$plants compared to WT.

\section{Protein analysis}

A histidine (His) tag had been added to the C-terminus of RfBP in the transformation construction and was used to facilitate purification of plant proteins by nickel chromatography $[13,76]$. The two youngest expanded leaves were excised and used in isolation of total proteins from $10 \mathrm{mg}$ fresh leaves as previously described [78]. Isolated proteins were bound to nickel-polystyrene beads according to the manufacturer's instruction (Amersham Biosciences Corp., Piscataway, NJ, USA), eluted with aqueous solutions of imidazole at 100,150, and $300 \mathrm{mM}$, respectively. The 200-mM imidazole eluent was treated with the Novagen Enterokinase Cleavage Capture Kit (EMD Biosciences Inc., Darmstadt, Germany) to remove the His tag and analyzed by tricine sodium dodecyl sulfate polyacrylamide gel electrophoresis [76]. Proteins were visualized by gel staining with Coomassie G-250.

\section{Pharmacological study}

The riboflavin feeding experiment was performed on plants grown in pots. Riboflavin (EMD Biosci. Inc., Darmstadt, Germany) was prepared as a $0.1 \mathrm{mM}$ aqueous solution, amended with $0.03 \%(\mathrm{v} / \mathrm{v})$ Silwet-L77 as a surfactant, and applied to 10-day-old plants by spraying plant tops with an atomizer [79]. Plants were treated similarly with an aqueous solution containing 0.03\% Silwet-L77 in the experimental control group. Two days later, shoot apices were excised as stated above and used in the analysis of $F D$ and $A P 1$ gene expression, and the two youngest expanded leaves were excised and used to detect the subcellular distribution and concentrations of $\mathrm{H}_{2} \mathrm{O}_{2}$, as well as expression of METC genes.

The effects of rotenone (Sigma-Aldrich, St. Luis, WA, USA) on METC gene expression and $\mathrm{H}_{2} \mathrm{O}_{2}$ concentrations were analyzed by experiments as for the riboflavin feeding experiment. Rotenone was prepared as a $40 \mathrm{mM}$ solution in $100 \%(\mathrm{v} / \mathrm{v})$ ethanol, diluted with water, and used at $40 \mu \mathrm{M}$ in an aqueous solution containing $0.1 \%$ ethanol to treat 10-day-old plants by spraying over plant tops. Plants were treated similarly with $0.1 \%$ ethanol in control. 
The effects of $\mathrm{H}_{2} \mathrm{O}_{2}$ and catalase (Sigma-Aldrich) on the intrinsic $\mathrm{H}_{2} \mathrm{O}_{2}$ concentrations and flowering time were determined using plants grown on MS medium in glass bottles $(5 \mathrm{~cm}$ high, 2 and $1.5 \mathrm{~cm}$ wide diametrically at top and bottom). Aqueous solutions of 4, 8, and $12 \mathrm{mM} \mathrm{H}_{2} \mathrm{O}_{2}$ and $5 \mu \mathrm{U} / \mathrm{ml}$ catalase were used after sterilization with $0.22 \mu \mathrm{m}$ cellulose filters. Seeds were sterilized and subjected to two types of experiments. The first type was devised to estimate functional dosage of $\mathrm{H}_{2} \mathrm{O}_{2}$ in a range of 0 (sterile water only), 4,8 , and $12 \mathrm{mM}$ applied in separate seed immersion. The second type of experiment was to test the combinative effect of $\mathrm{H}_{2} \mathrm{O}_{2}$ and catalase. Sterilized seeds were immersed with $4 \mathrm{mM} \mathrm{H}_{2} \mathrm{O}_{2}$ or $5 \mathrm{U} / \mathrm{ml}$ catalase or their mixture and immersed with sterile water in the experimental control group. Seed immersion was maintained six hours under room temperature and then washed with sterile water for five times under sterile conditions. Washed seeds were sowed on the medium in sterile 300-ml plastic bottles. Ten days later (when plants were seven days old), the medium were supplied with $5 \mu \mathrm{M} \mathrm{H}_{2} \mathrm{O}_{2}, 5 \mu \mathrm{U} / \mathrm{ml}$ catalase, or both and with sterile water in the control group. After incubation for additional two days, plants were used in the analysis of $F D$ and $A P 1$ expression in shoot apices and flavin concentrations in the two youngest expanded leaves. Flowering time and rosette leaf number were scored.

\section{$\mathrm{H}_{2} \mathrm{O}_{2}$ detection}

Subcellular localization of $\mathrm{H}_{2} \mathrm{O}_{2}$ was detected by fluorescent $\mathrm{H}_{2} \mathrm{O}_{2}$ probes Amplex Red (AR) and Amplex Ultra Red (AUR) (Invitrogen, San Diego, CA, USA) as previously described $[9,13,80]$. Both probes were used because previous observations showed that $A R$ and AUR were oxidized in reaction with $\mathrm{H}_{2} \mathrm{O}_{2}$ to emit strong crimson fluorescence $[9,81]$. The two youngest expanded leaves were excised and immediately immersed in the pH7.4 phosphate buffer solution containing $10 \mu \mathrm{M}$ AR or AUR, and were incubated within the solution in dark for 3 hours under a low pressure provided by a vacuum pump and a bell jar. Probed samples were observed under the ZEISS LSM700 laser scanning confocal microscope. The fluorescence emission of oxidized AR and AUR was observed between 585 and $610 \mathrm{~nm}$ using 543-nm argon laser excitation.

The content of $\mathrm{H}_{2} \mathrm{O}_{2}$ in plants was determined by quantifying the leaf $\mathrm{H}_{2} \mathrm{O}_{2}$ extract with a spectrophotometer. $\mathrm{H}_{2} \mathrm{O}_{2}$ was extracted from the first and second youngest leaves of 15-day-old plants and quantified by monitoring $\mathrm{A}_{415}$ of the titanium-peroxide complex formed with the $\mathrm{H}_{2} \mathrm{O}_{2}$ extract [26]. The content of $\mathrm{H}_{2} \mathrm{O}_{2}$ in plant leaves was determined according to the $\mathrm{A}_{415}$ curve of the titanium-peroxide complex formed with a range of standard $\mathrm{H}_{2} \mathrm{O}_{2}$ from a commercial source [26].

\section{Generation of the $\mathrm{RfBP}^{+} n f x 1$ hybrid}

$\mathrm{RfBP}^{+}$and $n f x 1$ plants were crossed on 10 days after flowering by pollinating atnfx 11 pistils with $\mathrm{RfBP}^{+}$microspore. $\mathrm{RfBP}^{+}$carries an IPT II gene [13], and $n f n x l 1$ carries IPT II and a T-DNA insert (http://signal.salk.edu/tdna_protocols. html). Therefore, the $\mathrm{RfBP}^{+} n f x l 1$ hybrid was identified based on growth in kanamycin-containing MS medium and PCR analyses of both RfBP and the insertion flanking sequence (Additional file 6: Table S1). The hybrid was self-crossed and its homologous F3 progenies were used in this study.

\section{Data analysis}

All experiments were carried out by completely randomized design and repeated at least three times with similar results. Quantitative data were analyzed with commercial IBM SPSS19.0 software package (IBM Corporation, Armonk, NY, USA; http://www-01.ibm.com/software/analytics/spss/). Homogeneity-of-variance in data was determined by Levene test, and formal distribution pattern of the data was confirmed by Kolmogorov-Smirnov test and P-P Plots [82]. Then, data were subjected to analysis of variance along with Fisher's least significant difference test [83] and Tukey-Kramer's test [84], respectively, using commercial SPSS19.0 software package.

\section{Availability of supporting data}

The microarray data supporting the results of this article are available in NCBI Gene Expression Omnibus repository (http://www.ncbi.nlm.nih.gov/geo/) under accession number GSE18417.

\section{Additional files}

Additional file 1: Figure S1. Relative levels of METC gene expression in $W T, R_{B B P}^{+}$, and RfBP ${ }^{-}$plants.

Additional file 2: Figure S2. Relative levels of METC gene expression in rotenone-treated and control plants.

Additional file 3: Figure S4. Relative levels of METC gene expression in $\mathrm{H}_{2} \mathrm{O}_{2}$-treated and control plants.

Additional file 4: Figure S5. Comparisons of $\mathrm{RfBP}^{+}$and Cat2 and NFXL1 mutations in $\mathrm{H}_{2} \mathrm{O}_{2}$ concentrations, $F D$ and $A P 1$ expression, and flowering time.

Additional file 5: Figure S3. The effect of rotenone on $\mathrm{H}_{2} \mathrm{O}_{2}$ concentrations in leaves.

Additional file 6: Table S1. Information on genes analyzed and primers used in this study.

\section{Abbreviations}

AP1: APETALA1; AR: Amplex red; AUR: Amplex ultra red; cat2: an Arabidopsis mutant with T-DNA-indexed CAT2 gene and decreased $\mathrm{H}_{2} \mathrm{O}_{2}$ content; CoQ: Ubiquinone; Cyt: Cytochrome; FAD: Flavin adenine dinucleotide; FMl: Floral meristem identity; FMN: Flavin mononucleotide;

METC: Mitochondrial electron transport chain; NAD: Nicotinamide adenine dinucleotide; $n f x$ 11: an Arabidopsis mutant with T-DNA-indexed NFXL1 gene and decreased $\mathrm{H}_{2} \mathrm{O}_{2}$ content; RfBP: Riboflavin-binding protein; $\mathrm{RfBP}^{+}$:

RfBP-expressing transgenic Arabidopsis line; RfBP $^{-}$: RfBP-silenced Arabidopsis line generated under $\mathrm{RfBP}^{+}$background; ROS: Reactive oxygen species. 


\section{Competing interests}

The authors have declared that no competing interests exist.

\section{Authors' contributions}

$\mathrm{LL}$ and $\mathrm{LH}$ performed the experiments and cowrote the paper. LPH analyzed the data. $H J, Y Z, X W, J G$, and MX performed the experiments. DS and HD designed the experiments and cowrote the paper. All authors read and approved the final manuscript.

\section{Acknowledgments}

We thank Dr. Shujian Zhang (former student in the lab) for the initial experiments. This study was supported by China National Key Basic Research Program (973 plan 2012CB114003), NSFC (31171830 and 31272072), and Novel Transgenic Organisms Breeding Project (2013ZX08002-001).

Received: 20 August 2014 Accepted: 11 December 2014 Published online: 30 December 2014

\section{References}

1. Weimar WR, Neims AH: Physical and chemical properties of flavin. In Riboflavin. Edited by Rivlin RS. New York: Plenum Press; 1975:2-36.

2. Jordan DB, Bacot KO, Carlson TJ, Kessel M, Viitanen PV: Plant riboflavin biosynthesis. Cloning, chloroplast localization, expression, purification, and partial characterization of spinach lumazine synthase. J Biol Chem 1999, 274:22114-22121.

3. Powers HJ: Riboflavin (vitamin B-2) and health. Am J Clin Nutr 2003, 77:1352-1360.

4. Torres MA, Jones JD, Dangl JL: Reactive oxygen species signaling in response to pathogens. Plant Physiol 2006, 141:373-378.

5. Gajewska E, Sklodowska M: Effect of nickel on ROS content and antioxidative enzyme activities in wheat leaves. Biometals 2007, 20:27-36.

6. Fernandez AP, Strand A: Retrograde signaling and plant stress: plastid signals initiate cellular stress responses. Curr Opin Plant Biol 2008, 11:509-513.

7. Piacenza L, Irigoín F, Alvarez MN, Peluffo G, Taylor MC, Kelly JM, Wilkinson SR, Radi R: Mitochondrial superoxide radicals mediate programmed cell death in Trypanosoma cruzi: cytoprotective action of mitochondrial iron superoxide dismutase overexpression. Bioch J 2007, 403:323-334.

8. Deng S, Yu MN, Wang Y, Jia Q, Lin L, Dong HS: The antagonistic effect of hydroxyl radical on the development of a hypersensitive response in tobacco. FEBS J 2010, 277:5097-5111.

9. Ashtamker C, Kiss V, Sagi M, Davydov O, Fluhr R: Diverse subcellular locations of cryptogein-induced reactive oxygen species production in tobacco Bright Yellow-2 cells. Plant Physiol 2007, 143:1817-1826.

10. Orrenius S, Gogvadze V, Zhivotovsky B: Mitochondrial oxidative stress: implications for cell death. Annu Rev Pharmacol Toxicol 2007, 47:143-183.

11. Torres MA: ROS in biotic interactions. Physiol Plant 2010, 138:414-429.

12. Sun LJ, Ren HY, Liu RX, Lü BB, Wu TQ, Sun F, Liu HM, Wang XM, Dong HS: An h-type thioredoxin functions in tobacco defense responses to two species of viruses and an abiotic oxidative stress. Mol Plant-Microbe Interact 2010, 23:1470-1485.

13. Deng BL, Deng S, Sun F, Zhang SJ, Dong HS: Down-regulation of free riboflavin content induces hydrogen peroxide and a pathogen defense in Arabidopsis. Plant Mol Biol 2011, 77:185-201.

14. Ott M, Gogvadze V, Orrenius S, Zhivotovsky B: Mitochondria, oxidative stress and cell death. Apoptosis 2007, 12:913-922.

15. Møller IM: Plant mitochondria and oxidative stress: electron transport, NADPH turnover, and metabolism of reactive oxygen species. Annu Rev Plant Physiol Plant Mol Biol 2001, 52:561-591.

16. Noctor G, Paepe RD, Foyer $\mathrm{CH}$ : Mitochondrial redox biology and homeostasis in plants. Trends Plant Sci 2007, 12:125-134.

17. Song XS, Wang YJ, Mao WH, Shi K, Zhou YH, Nogues S, Yu JQ: Effects of cucumber mosaic virus infection on electron transport and antioxidant system in chloroplasts and mitochondria of cucumber and tomato leaves. Physiol Plant 2009, 135:246-257.

18. Amirsadeghi $S$, Robson CA, McDonald AE, Vanlerberghe GC: Changes in plant mitochondrial electron transport alter cellular levels of reactive oxygen species and susceptibility to cell death signaling molecules. Plant Cell Physiol 2006, 47:1509-1519.

19. Lenaz G, Fato R, Genova ML, Bergamini C, Bianchi C, Biondi A: Mitochondrial complex I: structural and functional aspects. Bioch Biophys Acta 2006, 1757:1406-1420.
20. Alam G, Jones BC: Toxicogenetics: in search of host susceptibility to environmental toxicants. Front Genet 2014, 5:327.

21. Sanders LH, Greenamyre JT: Oxidative damage to macromolecules in human Parkinson disease and the rotenone model. Free Radic Biol Med 2013, 62:111-120.

22. Blokhina $\mathrm{O}$, Fagerstedt KV: Reactive oxygen species and nitric oxide in plant mitochondria: origin and redundant regulatory systems. Physiol Plant 2009, 138:447-462.

23. Gill SS, Tuteja N: Reactive oxygen species and antioxidant machinery in abiotic stress tolerance in crop plants. Plant Physiol Biochem 2010, 48:909-930.

24. Gleason C, Huang SB, Thatcher LF, Foley RC, Anderson CR, Carroll AJ, Millar AH, Singh KB: Mitochondrial complex II has a key role in mitochondrial-derived reactive oxygen species influence on plant stress gene regulation and defense. Proc Natl Acad Sci U S A 2011, 108:10768-10773.

25. Puente-Maestu L, Tejedor A, Lázaro A, de Miguel J, Alvarez-Sala L, GonzálezAragoneses F, Simón C, Agustí A: Site of mitochondrial reactive oxygen species production in skeletal muscle of chronic obstructive pulmonary disease and its relationship with exercise oxidative stress. Am J Respir Cell Mol Biol 2012, 47:358-362.

26. Zhang SJ, Yang X, Sun MW, Sun F, Deng S, Dong HS: Riboflavin-induced priming for pathogen defense in Arabidopsis thaliana. J Integr Plant Biol 2009, 51:167-174.

27. Hamajima $S$, Ono $S$ : Sequence of a cDNA encoding turtle riboflavin-binding protein: a comparison with avian riboflavin-binding protein. Gene 1995, 164:279-282.

28. Sabharanjak S, Mayor S: Folate receptor endocytosis and trafficking. Adv Drug Deliv Rev 2004, 56:1099-1109.

29. Bedhomme M, Hoffmann M, McCarthy EA, Gambonnet B, Moran RG Rébeillé F, Ravanel S: Folate metabolism in plants: an Arabidopsis homolog of the mammalian mitochondrial folate transporter mediates folate import into chloroplasts. J Biol Chem 2005, 280:34823-34831.

30. Bangaru MLY, Karande AA: Biochemical characterization of recombinant chicken riboflavin carrier protein. Mol Cell Biochem 2008, 308:1-7.

31. Lokhande SD, Ogawa K, Tanaka A, Hara T: Effect of temperature on ascorbate peroxidase activity and flowering of Arabidopsis thaliana ecotypes under different light conditions. J Plant Physiol 2003, 160:57-64.

32. Bañuelos GR, Argumedo R, Patel K, Ng V, Zhou F, Vellanoweth RL: The developmental transition to flowering in Arabidopsis is associated with an increase in leaf chloroplastic lipoxygenase activity. Plant Sci 2008, 174:366-373.

33. Shen $\mathrm{CH}$, Krishnamurthy $\mathrm{R}$, Yeh KW: Decreased L-ascorbate content mediating bolting is mainly regulated by the galacturonate pathway in Oncidium. Plant Cell Physiol 2009, 50:935-946.

34. Zafra A, Rodríguez-García MI, Alché JD: Cellular localization of ROS and NO in olive reproductive tissues during flower development. BMC Plant Biol 2010, 10:36.

35. Lai AG, Doherty CJ, Mueller-Roeber B, Kay SA, Schippers JH, Dijkwel PP: CIRCADIAN CLOCK-ASSOCIATED 1 regulates ROS homeostasis and oxidative stress responses. Proc Natl Acad Sci U S A 2012, 109:17129-17134.

36. Jack T: Molecular and genetic mechanisms of floral control. Plant Cell 2004, 16:S1-S17.

37. Giakountis A, Coupland G: Phloem transport of flowering signals. Curr Opin Plant Biol 2008, 11:687-694.

38. Abe M, Kobayashi $Y$, Yamamoto S, Daimon $Y$, Yamaguchi A, Ikeda Y, Ichinoki H, Notaguchi M, Goto K, Araki T: FD, a bZIP protein mediating signals from the floral pathway integrator FT at the shoot apex. Science 2005, 309:1052-1056.

39. Wigge PA, Kim MC, Jaeger KE, Busch W, Schmid M, Lohmann JU, Weigel D: Integration of spatial and temporal information during floral induction in Arabidopsis. Science 2005, 309:1056-1059.

40. Ji HT, Zhu YY, Tian S, Xu MY, Tian YM, Li L, Wang H, Hu L, Ge J, Wen WG, Dong HS: Downregulation of leaf flavin content induces early flowering and photoperiod gene expression in Arabidopsis. BMC Plant Biol 2014, 14:237.

41. Jung C, Müller AE: Flowering time control and applications in plant breeding. Trends Plant Sci 2009, 14:563-573.

42. Mutasa-Göttgens E, Hedden P: Gibberellin as a factor in floral regulatory networks. J Exp Bot 2009, 60:1979-1989.

43. Simpson GG: The autonomous pathway: epigenetic and post-transcriptional gene regulation in the control of Arabidopsis flowering time. Curr Opin Plant Biol 2004, 7:570-574. 
44. Más P, Yanovsky MJ: Time for circadian rhythms: plants get synchronized. Curr Opini Plant Biol 2009, 12:574-579.

45. Suárez-López P, Wheatley K, Robson F, Onouchi H, Valverde F, Coupland G: CONSTANS mediates between the circadian clock and the control of flowering in Arabidopsis. Nature 2001, 410:1116-1120.

46. Martinez-Garcia JF, Huq E, Quail PH: Direct targeting of light signals to a promoter element-bound transcription factor. Science 2000, 288:859-863.

47. Yoo SK, Chung KS, Kim J, Lee JH, Hong SM, Yoo SJ, Yoo SY, Lee JS, Ahn JH: CONSTANS activates SUPPRESSOR OF OVEREXPRESSION OF CONSTANS 1 through FLOWERING LOCUS T to promote flowering in Arabidopsis. Plant Physiol 2005, 139:770-778.

48. Bueso E, Alejandro S, Carbonell P, Perez-Amador MA, Fayos J, Bellés JM, Rodriguez PL, Serrano R: The lithium tolerance of the Arabidopsis cat2 mutant reveals a cross-talk between oxidative stress and ethylene. Plant $J$ 2007, 52:1052-1065.

49. Queval G, Issakidis-Bourguet E, Hoeberichts FA, Vandorpe M, Gakière B, Vanacker H, Miginiac-Maslow M, Van Breusegem F, Noctor G: Conditional oxidative stress responses in the Arabidopsis photorespiratory mutant cat 2 demonstrate that redox state is a key modulator of daylength-dependent gene expression and define photoperiod as a crucial factor in the regulation of $\mathrm{H}_{2} \mathrm{O}_{2}$-induced cell death. Plant J 2007, 52:640-657.

50. Lisso J, Altmann T, Müssig C: The AtNFXL1 gene encodes a NF-X1 type zinc finger protein required for growth under salt stress. FEBS Lett 2006, 580:4851-4856.

51. Grivennikova VG, Vinogradov AD: Generation of superoxide by the mitochondrial Complex I. Bba-Bioenergetics 2006, 1757:553-561.

52. Srikanth A, Schmid M: Regulation of flowering time: all roads lead to Rome. Cell Mol Life Sci 2011, 68:2013-2037.

53. Roje S: Vitamin B biosynthesis in plants. Phytochemistry 2007, 68:1904-1921.

54. Xiao S, Dai L, Liu F, Wang Z, Peng W, Xie D: COS1: An Arabidopsis coronatine insensitive 1 suppressor essential for regulation of jasmonate-mediated plant defense and senescence. Plant Cell 2004, 16:1132-1142.

55. Peng JL, Zhao J, Pan XM, Zhao JS, Dong HS, Wang JS, Liu BX, Liu GY, Cheng YJ: Riboflavin activates growth signal transduction pathway in plants. J Nanjing Agr Univ 2002, 25:33-36.

56. Sandoval FJ, Roje S: An FMN hydrolase is fused to a riboflavin kinase homolog in plants. J Biol Chem 2005, 280:38337-38345.

57. Giancaspero TA, Locato V, de Pinto MC, Gara LD, Barile M: The occurrence of riboflavin kinase and FAD synthetase ensures FAD synthesis in tobacco mitochondria and maintenance of cellular redox status. FEBS J 2009, 276:219-231.

58. Birky CW: The inheritance of genes in mitochondria and chloroplasts: laws, mechanisms and models. Annu Rev Genet 2001, 35:125-148.

59. Huang SN, Swaan PW: Involvement of a receptor-mediated component in cellular translocation of riboflavin. J Pharmacol Exp Ther 2000, 294:117-125.

60. Foraker AB, Khantwal CM, Swaan PW: Current perspectives on the cellular uptake and trafficking of riboflavin. Adv Drug Deliv Rev 2003, 55:1467-1483.

61. Gastaldi G, Laforenza U, Casirola D, Ferrari G, Tosco M, Rindi G: Energy depletion differently affects membrane transport and intracellular metabolism of riboflavin taken up by isolated rat enterocytes. J Nutr 1999, 129:406-409.

62. Said HM, Mohammed ZM: Intestinal absorption of water-soluble vitamins: An update. Curr Opin Gastroen 2006, 22:140-146.

63. Rasmusson $\mathrm{AG}$, Soole $\mathrm{KL}$, Elthon $\mathrm{TE}$ : Alternative $\mathrm{NAD}(\mathrm{P}) \mathrm{H}$ dehydrogenases of plant mitochondria. Annu Rev Plant Biol 2004, 55:23-39.

64. Xiong N, Long X, Xiong J, Jia M, Chen C, Huang J, Ghoorah D, Kong X, Lin Z, Wang T: Mitochondrial complex I inhibitor rotenone-induced toxicity and its potential mechanisms in Parkinson's disease models. Crit Rev Toxicol 2012, 42:613-632.

65. Garmier M, Carroll AJ, Delannoy E, Vallet C, Day DA, Small ID, Millar AH: Complex I dysfunction redirects cellular and mitochondrial metabolism in Arabidopsis. Plant Physiol 2008, 148:1324-1341.

66. Delaunay A, Pflieger D, Barrault MB, Vinh J, Toledano MB: A thio peroxidase is an $\mathrm{H}_{2} \mathrm{O}_{2}$ receptor and redox-transducer in gene activation. Cell 2002, 111:471-481

67. Ludewig U, Dynowski M: Plant aquaporin selectivity: where transport assays, computer simulations and physiology meet. Cell Mol Life Sci 2009, 66:3161-3175

68. Hachez C, Chaumont F: Aquaporins: a family of highly regulated multifunctional channels. Adv Exp Med Biol 2010, 679:1-17.
69. Cramer MD, Hawkins HJ, Verboom GA: The importance of nutritional regulation of plant water flux. Oecologia 2009, 161:15-24.

70. Gomes D, Agasse A, Thiébaud P, Delrot S, Gerós H, Chaumont F Aquaporins are multifunctional water and solute transporters highly divergent in living organisms. Biochim Biophys Acta 2009, 1788:1213-1228.

71. Knipfer T, Besse M, Verdeil $J$, Fricke W: Aquaporin-facilitated water uptake in barley (Hordeum vulgare L.) roots. J Expl Bot 2011, 62:4115-4126.

72. Ali W, Isayenkov SV, Zhao FJ, Maathuis FJ: Arsenite transport in plants. Cell Mol Life Sci 2009, 66:2329-2339.

73. Verbruggen $\mathrm{N}$, Hermans $\mathrm{C}$, Schat H: Mechanisms to cope with arsenic or cadmium excess in plants. Curr Opin Plant Biol 2009, 12:364-372.

74. Hooijmaijers C, Rhee JY, Kwak KJ, Chung GC, Horie T, Katsuhara M, Kang H: Hydrogen peroxide permeability of plasma membrane aquaporins of Arabidopsis thaliana. J Plant Res 2011, 125:147-153.

75. Dong HP, Yu HY, Bao ZL, Guo XJ, Peng JL, Yao Z, Chen GY, Qu SP, Dong HS: The ABI2-dependent abscisic acid signalling controls HrpN-induced drought tolerance in Arabidopsis. Planta 2005, 221:313-327.

76. Chen L, Qian J, Qu SP, Long JY, Yin Q, Zhang CL, Wu XJ, Sun F, Wu TQ, Hayes $M$, Beer SV, Dong HS: Identification of specific fragments of HpaGXooc, a harpin from Xanthomonas oryzae pv. oryzicola, that induce disease resistance and enhance growth in plants. Phytopathology 2008, 98:781-791.

77. Liu RX, Chen L, Jia ZH, Lü BB, Shi HJ, Shao WL, Dong HS: Transcription factor AtMYB44 regulates induced expression of the ETHYLENE INSENSITIVE2 gene in Arabidopsis responding to a harpin protein. Mol Plant-Microbe Interact 2011, 24:377-389.

78. Sang SL, Li XJ, Gao R, You ZZ, Lü BB, Liu PQ, Dong HS: Apoplastic and cytoplasmic location of harpin protein $\mathrm{Hpa} 1_{\text {xoo }}$ plays different roles in $\mathrm{H}_{2} \mathrm{O}_{2}$ generation and pathogen resistance in Arabidopsis. Plant Mol Biol 2012, 79:375-391.

79. Dong HS, Beer SV: Riboflavin induces disease resistance in plants by activating a novel signal transduction pathway. Phytopathology 2000 , 90:801-811.

80. Šnyrychová I, Ayaydin F, Hideg É: Detecting hydrogen peroxide in leaves in vivo - a comparison of methods. Physiol Plant 2009, 135:1-18.

81. Rhee SG, Chang TS, Jeong W, Kang D: Methods for detection and measurement of hydrogen peroxide inside and outside of cells. Mol Cell 2010, 29:539-549.

82. Shi LW: SPSS19.0 Statistical Analysis from Accidence to Conversance (in Chinese), Volume 19. Beijing: Tsinghua Univ Press; 2012:109-143.

83. Li XJ, Han B, Xu MY, Han LP, Zhao YY, Liu ZL, Dong HS, Zhang CL: Plant growth enhancement and associated physiological responses are coregulated by ethylene and gibberellin in response to harpin protein Hpa1. Planta 2014, 239:831-846.

84. Ludbrook J: Multiple comparison procedures updated. Clin Exp Pharmacol Physiol 1998, 25:1032-1037.

85. Thimm O, Bläsing $O$, Gibon $Y$, Nagel A, Meyer $S$, Krüger $P$, Selbig J, Mülle LA, Rhee SY, Stitt M: MAPMAN: a user-driven tool to display genomics data sets onto diagrams of metabolic pathways and other biological processes. Plant J 2004, 37:914-939.

\section{Submit your next manuscript to BioMed Central and take full advantage of:}

- Convenient online submission

- Thorough peer review

- No space constraints or color figure charges

- Immediate publication on acceptance

- Inclusion in PubMed, CAS, Scopus and Google Scholar

- Research which is freely available for redistribution 